Roger Williams University

DOCS@RWU

Winter 2020

\title{
In West Philadelphia Born and Raised or Moving to Bel-Air? Racial Steering as a Consequence of Using Race Data on Real Estate Websites
}

Nadiyah J. Humber

Roger Williams University School of Law

Follow this and additional works at: https://docs.rwu.edu/law_fac_fs

Part of the Civil Rights and Discrimination Commons, Housing Law Commons, Law and Race Commons, Property Law and Real Estate Commons, and the Social Welfare Law Commons

\section{Recommended Citation}

Nadiyah J. Humber, In West Philadelphia Born and Raised Or Moving to Bel-Air: Racial Steering as a Consequence of Using Race Data on Real Estate Websites, 17 Hastings Race \& Poverty L.J. 133 (2020).

This Article is brought to you for free and open access by the Law Faculty Scholarship at DOCS@RWU. It has been accepted for inclusion in Law Faculty Scholarship by an authorized administrator of DOCS@RWU. For more information, please contact mwu@rwu.edu. 


\section{HEINONLINE}

Content downloaded/printed from

HeinOnline

Wed Feb 5 14:45:40 2020

Citations:

Bluebook 20th ed.

Nadiyah J. Humber, In West Philadelphia Born and Raised Or Moving to Bel-Air: Racial Steering as a Consequence of Using Race Data on Real Estate Websites, 17 Hastings Race \& Poverty L.J. 133 (2020).

ALWD 6th ed.

Nadiyah J. Humber, In West Philadelphia Born and Raised Or Moving to Bel-Air: Racial Steering as a Consequence of Using Race Data on Real Estate Websites, 17 Hastings Race \& Poverty L.J. 133 (2020).

APA 6th ed.

Humber, N. J. (2020). In west philadelphia born and raised or moving to bel-air: Racial steering as consequence of using race data on real estate websites. Hastings Race and Poverty Law Journal, 17(1), 133-176.

Chicago 7th ed.

Nadiyah J. Humber, "In West Philadelphia Born and Raised Or Moving to Bel-Air: Racial Steering as a Consequence of Using Race Data on Real Estate Websites," Hastings Race and Poverty Law Journal 17, no. 1 (Winter 2020): 133-176

McGill Guide 9th ed.

Nadiyah J Humber, "In West Philadelphia Born and Raised Or Moving to Bel-Air: Racial Steering as a Consequence of Using Race Data on Real Estate Websites" (2020) 17:1 Hastings Race \& Poverty LJ 133.

MLA 8th ed.

Humber, Nadiyah J. "In West Philadelphia Born and Raised Or Moving to Bel-Air: Racial Steering as a Consequence of Using Race Data on Real Estate Websites." Hastings Race and Poverty Law Journal, vol. 17, no. 1, Winter 2020, p. 133-176. HeinOnline.

OSCOLA 4th ed.

Nadiyah J Humber, 'In West Philadelphia Born and Raised Or Moving to Bel-Air: Racial Steering as a Consequence of Using Race Data on Real Estate Websites' (2020) 17 Hastings Race \& Poverty LJ 133

Provided by:

Roger Williams University School of Law Library

-- Your use of this HeinOnline PDF indicates your acceptance of HeinOnline's Terms and Conditions of the license agreement available at https://heinonline.org/HOL/License

-- The search text of this PDF is generated from uncorrected OCR text.

-- To obtain permission to use this article beyond the scope of your license, please use: 


\title{
In West Philadelphia Born and Raised or Moving to Bel-Air? Racial Steering as a Consequence of Using Race Data on Real Estate Websites
}

\author{
NADIYAH J. HUMBER ${ }^{*}$
}

\begin{abstract}
Current fair housing laws are not entirely equipped to deal with issues of housing discrimination on the internet, particularly the practice of racial steering, where a homebuyer is directed away from certain communities based on racial demographics. Courts interpret these kind of steering claims as requiring a showing of discriminatory intent, yet the way people search for and buy homes online have changed how steering manifests in real estate transactions. Contemporary practices do not fit neatly within the current legal framework, which is why we must revolutionize the way we think about housing law.

This article examines real estate websites, like Zillow Group and Redfin - two leading companies that are closely intertwined with the practice of industry professionals-and suggests that race data that has been posted on these platforms are problematic. Testing studies show that race information and school quality have been used and are still being used by real estate professionals to steer White homebuyers away from communities of color, thereby reinforcing segregation patterns. The article illuminates issues of online steering within the legal framework of the Fair Housing Act ("FHA"), Communications Decency Act, and relevant case law. It suggests two recommendations for addressing the use of race data on real estate

* Nadiyah J. Humber is an Assistant Clinical Professor of Law at Roger Williams University School of Law. Professor Humber directs the Corporate Counsel, Prosecution and Government Clinical Externship Programs. Prior to her appointment, Nadiyah was the Director of Investigations and Outreach, Clinical Fellow at Suffolk University Law School's Housing Discrimination Testing Program. Nadiyah would like to thank all faculty who assisted her with this research project. Thank you Susan Bennett, Patience Crowder, Sherley Cruz, Kathleen Engel, Deborah Gonzalez, Norrinda Hayat, Matthew Rossman, Ragini Shah, and all members of the Suffolk University Law School Junior Faculty Workshop. A special thank you to research assistants Benjamin Eddington and Isimemen T. Ehikhamhen, as well as Richard Buckingham, Ana Isabel Delgado Valentin, and AnnaKatherine Wherren of Moakley Law Library.
\end{abstract}


websites: (1) using discriminatory effect theory as a litigation strategy and (2) amending the FHA to cover online real estate marketplaces.

\section{Introduction}

Consider an advertisement that posted the following text: "Welcome to the neighborhood! The moment you step inside this featured home you will fall in love with this meticulously maintained three-bedroom colonial. Features include hardwood floors, central air conditioning, a bright and spacious living room with a fireplace, full bath, and an open concept dining room and kitchen. Come on by, kick off your shoes and experience the lush green grass of the flawlessly manicured lawn under your feet. This is the home of your dreams! But please note, the school district has a rating of 3 out of 10 , with Black children making up about $60 \%$ of the student population and Latino children, 20\%."

After reading this advertisement, it is fair to say that depending on community preference, a homebuyer will inevitably decide to either tour the home or look at another listing while considering the racial makeup of the school's catchment area. ${ }^{1}$ The language in the above advertisement was created for the purpose of illustration; however, the functional equivalent of the above advertisement existed on real estate websites as recently as $2017^{2}$ and could easily reappear at the discretion of these companies. Homebuyers can view agent listings and click an arrow to expand drop-downs that chart racial demographics of neighborhood schools. The race content is generated by for-profit institutions. ${ }^{3}$ These third-party companies develop charts that are displayed beside property listings. Homebuyers can review school names, grade levels, rankings, distance of schools from listing locations,

1 Education Demographic and Geographic Estimates, NAT'L CTR FOR EDUC. STATISTICS, https://nces.ed.gov/programs/edge/SABS (last visited Aug. 14, 2018) (defining, in part, catchment areas). Attendance boundaries, sometimes known as school catchment areas, define the geographic extent served by a local school for the purpose of student assignments. Id.

2. See Zillow, Excel Academy Charter School (Oct. 19, 2019) http://web.archive.org/web/ 20130910032902/http:/www.zillow.com/boston-ma/schools/excel-academy-charter-school-22 559/, Zillow, Boston Collegiate Charter School (Oct. 19, 2019) http://web.archive.org/web/ 20130723055547/http:/www.zillow.com/boston-ma/schools/boston-collegiate-charter-school-22 387/andHammanHomes, Franklin Elementary School (Oct. 19, 2019) http://www.hamman homes.com/app/school/530870001467 (showing racial demographics of school children at educational institutions linked to specific real estate agent property listings).

3. See About Us, GREATSCHOOLS.ORG, https://www.greatschools.org/. GreatSchools.org is a nonprofit that provides ratings and school information online. Id. The site claims to help families choose the best school for their children by providing reports, data, and graphs. Id. It is commonly used by community stakeholders and real estate websites. Id.; see What Sets Niche Apart, NiCHE: OvERVIEw, https://www.niche.com/about/ (last visited Oct. 3, 2019). Niche.com provides data sets related to colleges, schools $\mathrm{K}-12$, neighborhoods, and companies. Id. The site provides report cards, rankings, and reviews for consumers to analyze. $I d$. 
standardized test charts for schools, and race and ethnicity information of students enrolled at particular schools. The display of race data linked to property advertisements online is reminiscent of earlier practices by real estate agents who used school quality as a proxy for race. ${ }^{4}$ When race data is posted on real estate platforms, the demographics of school children are reflective of the neighborhood, and this information can steer homebuyers of a different racial makeup away from those communities, thereby reinforcing segregation patterns. ${ }^{5}$ Additionally, school ranking charts (where race data is embedded) commonly use underdeveloped metrics that do not accurately reflect school quality and are borderline misleading. ${ }^{6}$

Steering as a consequence of using race data on real estate websites is a novel legal issue. The recommendations for addressing the practice of posting race data on real estate websites are also original. Current fair housing laws are not entirely equipped to deal with issues of discrimination in technology. For example, courts interpret steering claims as requiring a showing of discriminatory intent. ${ }^{7}$ The practice of posting race data online does not fit within the current legal definition of steering, despite the fact that providing race data during an in-person interaction would likely constitute illegal steering. Under current laws, it is difficult and potentially impractical to establish that a real estate website, in and of itself, has intent to steer when posting race data in property listings. Public policy considerations related to discriminatory advertisements are consistent with concerns about posting race data in property listings. The article discusses whether real estate websites implicate fair housing laws prohibiting discriminatory preferences in advertisements.

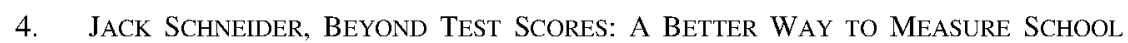
QUALITY 3 (2017) (highlighting parents' tendencies to use race as proxy for school quality).

5. Id. (noting that middle-class white parents often shy away from schools with large concentrations of black and brown students); see generally, Micere Keels et al., The Effects of Gentrification on Neighborhood Public Schools, 12 CITY \& CMTY 238, 241-42 (2013) (studying the effects of gentrification and segregation in Chicago public schools as it relates to school choice by higher educated, higher income, and nonminority parents); David R. Garcia, The Impact of School Choice on Racial Segregation in Charter Schools, 22 EDUC. POL'Y 805 (2008) (discussing the potential of school choice to desegregate due to charter schools not being tied to catchment areas; yet, research shows choice has exacerbated segregation not remedied it).

6. SCHNEIDER, supra note 4, at 65-68 (highlighting methodological flaws in school ranking data used by GreatSchools.org and Niche.com). Data on GreatSchools.org is based on raw SAT IACT test scores and test score growth which is highly correlated with family income. Id. Niche.com allots $25 \%$ of weight to test scores. Id. Schneider notes that methodologies of Greatschools.org and Niche.com are misleading, exacerbate stereotypes, and pit schools against each other with a one-size-fits-all approach. Id.

7. Heights Cmty. Congress v. Hilltop Realty, Inc., 774 F.2d 135, 139-41 (6th Cir. 1985) (holding that a statement or act by an agent that has a discriminatory effect and is made with intent to steer violates $\$ 3604(a)$ ). 
Questions about content on the internet must also be considered within the context of the Communications Decency Act ("CDA"). ${ }^{8}$ The CDA allows for online platforms to have the freedom to display information on the internet that may not otherwise be permitted in print format or in-person transactions. However, experts have shown that if businesses, like Airbnb, Homeaway.com, and in this case, real estate market places, conduct activities outside the function of mere publishing, these businesses as a whole may not necessarily benefit from CDA protection. ${ }^{9}$ The article examines Zillow Group and Redfin, two leading companies that are closely intertwined with the practice of industry professionals. The analysis suggests that real estate websites manage their platforms in a manner that would likely exempt them from CDA protection.

It is true that the CDA's ideals - to promote freedom of content on the internet by limiting the liability of publishers-support an essential social function. The internet opens up the world to common people, and as a matter of public policy, it is important to promote data integrity so the public can remain informed. In turn, race data on the internet alone is not the issue. Rather, the concern raised in this paper is that race information featured and displayed beside real estate listings are problematic due to the historical use of race information to steer White homebuyers away from communities of color. The article discusses two proposals for addressing this modern issue of online steering.

Section I of the article outlines a brief history of the Black experience related to home ownership and the culture and frequency of racial steering in the real estate industry. Section II discusses current fair housing laws as it relates to the CDA and illuminates on issues of online steering within the present legal framework. Section III suggests two recommendations for addressing the use of race data on real estate websites: (1) using segregative effect theory ${ }^{10}$ as a litigation strategy and (2) amending the FHA to cover online real estate marketplaces.

8. 47 U.S.C. $\$ 230$ (2018) (protecting freedom of content on the internet).

9. Brief of Internet, Business, and Local Government Law Professors as Amici Curiae Supporting the Respondents at 13, Homeaway.com \& Airbnb, Inc. v. City of Santa Monica, Nos. 2:16-cv-06641-ODW, 2:16-cv-06645-ODW (9th Cir. May 23, 2018). Airbnb and Homeaway.com sued to enjoin the City of Santa Monica from enforcing an Ordinance compelling these platforms to obtain licensing required to facilitate booking transactions of short-term rentals. Id. Order Denying Plaintiffs' Motion for Preliminary Injunction at 1-2, Homeaway.com \& Airbnb, Inc. v. City of Santa Monica, Nos. 2:16-cv-06641-ODW, 2:16-cv-06645-ODW (9th Cir. May 23, 2018). Airbnb and Homeaway.com argued the Ordinance violated the CDA because it protects websites from liability based on content supplied by third parties. Id. See also 47 U.S.C. § 230 (2018), supra note 8. The Ninth Circuit denied Plaintiffs' motion and agreed with the City that CDA protection did not extend to activities in which Plaintiffs' engaged, as they extended beyond mere publishing of third-party content. $I d$. at 5 .

10. See 24 C.F.R. $\$ 100.500$ (2017). The C.F.R. states "[1]iability may be established under 


\section{Brief History of The Real Estate Market and Race}

In order to appreciate why posting race data on real estate websites is a new form of racial steering that reinforces patterns of segregation, how and why racial steering became so engrained in the practice of real estate requires careful consideration. Prior to the passing of the Fair Housing Act ${ }^{11}$ in 1968, the real estate industry and agent practices were one of many contributors to structural racism against minorities in American history. ${ }^{12}$ The following section focuses primarily on the exclusion of Blacks from land ownership opportunity. It discusses progressive reform efforts that were good in theory, but without enforcement had no significance in the daily lives of Black Americans.

\section{A. A Black Person's Right to Buy and Sell Property}

Systemic oppression of Black people in America was codified by omission when the founding fathers rejected the term "slavery" from draft versions of the Declaration of Independence, thereby excluding Blacks from sovereign ideology. ${ }^{13}$ Supporters of the Thirteenth Amendment sought to achieve equality by enacting legislation to abolish slavery and involuntary servitude. ${ }^{14}$ However, it was soon realized that although slavery was abolished, the law did not help to attain equality for Blacks. Revolutionary efforts like "forty acres and a mule" 15 ordered by General William T.

the Fair Housing Act based on a practice's discriminatory effect ... even if the practice was not motivated by a discriminatory intent." See id.; see also 24 C.F.R. $\$ 100.500$ (a) (2017). Discriminatory effect is defined as "a practice ... where it actually or predictably results in a disparate impact on a group of persons or creates, increases, reinforces, or perpetuates segregated housing patterns because of race, color, religion, sex, handicap, familial status, or national origin." Id.

11. 42 U.S.C. $\$ 3604$ (2019).

12. See generally, RiCHARd RothStein, THE COlOR OF LAw: A Forgotten History OF HOw OUR GOVERNMENT SEGREGATED AMERICA (2017) (underscoring participation of private and government actors in the segregation of modern American cities).

13. See Rough Draft of the Declaration of Independence, PBS: KQED, http://www.pbs.org/ wgbh/aia/part2/2h33.html (last visited Oct. 4, 2019). A version of the Declaration of Independence, written by Thomas Jefferson, was presented to the Continental Congress on July 1 , 1776. Id. Jefferson's original document included language denouncing slavery. Id. After debate by both northern and southern slave holders, the final text excluded any mention of slavery. Id.

14. Hugh E. Hackney, Racial Discrimination and the Civil Rights Act of 1866, 23 Sw. L. REV. 373, 376 (1969) (explaining the origins of the thirteenth amendment and 1866 Civil Rights Act).

15. Henry Louis Gates, Jr., The Truth Behind ' 40 Acres and a Mule', THE ROOT, https://www.theroot.com/the-truth-behind-40-acres-and-a-mule-1790894780 (last visited Feb. 3, 2019) (discussing the historical accuracy of land promised to newly freed slaves). Had the policy been implemented and enforced, allowing former slaves to own land and property, to be selfsufficient economically, and to build, accrue and pass on wealth, the United States would be a 
Sherman during the Lincoln administration were reversed by the following Johnson administration-an upset that has negatively impacted Blacks for centuries. ${ }^{16}$ As a result, Senator Lyman Trumbull ${ }^{17}$ authored a bill with a stated purpose to "secure for all men 'the great and fundamental rights' and 'break down all discrimination between black and white men." 18 The proposed bill was known as the 1866 Civil Rights Act, which required that all citizens of the United States shall have the same rights as White citizens, including in the conveyance of real property. ${ }^{19}$ Questions arose early on as to whether or not the 1866 Civil Rights Act pertained only to state action or extended to private action of individuals based on the fact that it was reenacted verbatim after the passing of the fourteenth amendment. ${ }^{20}$

In the Civil Rights Cases of $1883,{ }^{21}$ the Supreme Court, in dicta, confirmed that Congress had no power to prohibit purely private discrimination, including discrimination in housing transactions. ${ }^{22}$ The next time the Supreme Court considered the 1866 Act was in 1925, when they sided with defendants and permitted discrimination in public accommodations and housing through use of restrictive covenants. ${ }^{23}$ The Supreme Court did not provide a clear answer regarding the depth and breadth of the 1866 Act as it pertained to private action and power of enforcement under the thirteenth amendment for over 100 years.

For ten decades, discrimination in the sale and rental of private housing was permitted by the government and was regularly practiced by real

different place. $I d$.

16. See also Reconstruction, BRITANNICA, https://www.britannica.com/event/Reconstruct ion-United-States-history\#ref1096633 (last visited Feb. 18, 2019) (noting Field Order No. 15 of January 1865 by of General William T. Sherman under radical reconstruction),

17. Hackney, supra note 14, at 376 n. 24 (discussing Senator Trumbull of Illinois a leader for civil rights legislation). (1866)).

18. Hackney, supra note 14, at 376 n. 25-26 (citing CONG. GlOBE, 39th Cong., 1st Sess. 475

19. 42 U.S.C. \$ 1982 (1964) (stating "All citizens of the United States shall have the same right, in every State and Territory, as is enjoyed by white citizens thereof to inherit, purchase, lease, sell, hold, and convey real and personal property.") $I d$.

20. Hackney, supra note 14, at 376 (discussing Congressional intent of the Thirteenth Amendment and the re-enactment of 1866 Civil Rights Act after the Fourteenth Amendment).

21. Civil Rights Cases, 109 U.S. 3 (1883) (reiterating the 1866 Civil Right Act's lack of jurisdiction over private housing discrimination).

22. Hackney, supra note 14, at 377-78 (discussing rulings of Civil Rights Cases of 1883). The 1883 decisions weakened the enforcement power of the 1866 Civil Rights Act. Id.

23. Hackney, supra note 14, at 377-78 (citing Corrigan v. Buckley, 7271 U.S. 323 (1925)) The Court in Buckley held that "no violation of the thirteenth amendment existed because it applied only to the situations in which slavery or involuntary servitude was forced upon the Negro and therefore did not prohibit discrimination in housing by use of racially restrictive covenants." Id.; Hackney, supra note 14, at 379 (citing Hurd v. Hodge, 334 U.S. 24 (1948)). The Court did not answer the question of whether the 1866 Act extended to private actions, but because the holding was based on the fourteenth amendment, "Hurd may support the view that Congress did not intend the 1866 Act to apply to private discrimination." Id. 
estate professionals and private owners. It was not until 1968, in Jones $v$. Alfred $H$. Mayer Co. ${ }^{24}$ that the Supreme Court established a clear interpretation of how the thirteenth amendment provided the legislative foundation for the enforcement of the 1866 Act. In Jones, the petitioner sought to buy property from respondent Alfred H. Mayer Co., a real estate agency. ${ }^{25}$ Jones, the petitioner, claimed that agents of the company refused to sell the property to him and his wife for the sole reason that they were Black. $^{26}$ The federal district court dismissed the complaint on the basis that the 1866 Act applied only to state actions and not to the actions of private persons in refusing to sell property. ${ }^{27}$ The eighth circuit court of appeals affirmed..$^{28}$ The Supreme Court reversed, holding that that the 1866 Act "was a valid exercise of the power of Congress to enforce the thirteenth amendment and that Congress had intended thereby to prohibit all private as well as public discrimination on the basis of race in the sale or rental of property." 29

Though the Jones decision, finalized on June 17, 1968, brought the nation one step closer to equal housing for all citizens, its usefulness was greatly reduced by the passage of the Fair Housing Act ("FHA") just two months prior on April 11, 1968. The FHA was signed into law by President Lyndon B. Johnson and expanded on protections afforded by its predecessors-Equal Pay Act of $1963,{ }^{30}$ the Civil Rights Act of $1964,{ }^{31}$ and the Voting Rights Act of $1965^{32}$ - by prohibiting discrimination in the sale or rental of real property on the basis of race, religion, national origin and sex; and was later amended in $1988^{33}$ to include handicap and familial status. ${ }^{34}$ Despite the passage of the Fair Housing Act, illegal discrimination remains a common practice in the real estate profession.

In the remainder of Section I, the article reflects on the prevalence of racial steering in the real estate profession both before and after the passing of the Fair Housing Act in 1968. It was not until 1979 that racial steering was defined by the Supreme Court as "directing prospective home buyers

24. Jones v. Alfred H. Mayer Co., 392 U.S. 409 (1968).

25. Hackney, supra note 14, at 380 (explaining that whether the 1866 Act applied to private actions remained unanswered until 1968).

26. Jones v. Alfred H. Mayer Co., 392 U.S. 409, 412-13 (1968).

27. Id.

28. Id.

29. Id. at 413; see also Hackney, supra note 13, at 380 (describing the Court's application of the 1866 Act to private action for the first time); see also ROTHSTEIN, supra note 11, at viii-ix.

30. Equal Pay Act of 1963, Pub. L. No. 88-38, 77 Stat. 56 (1963).

31. Civil Rights Act of 1964, 42 U.S.C. $\$ 2000 \mathrm{e}$ et. seq. (1964).

32. Voting Rights Act of 1965, Pub. L. 89-110, 79 Stat. 437 (1965).

33. See Robert G. Schwemm, Housing Discrimination Law and Litigation ch. $5, \S 3$ (2018) (providing further details on the legislative history of the 1988 Amendments).

34. 42 U.S.C. $\$ \S 3604$ (c) - (f) (2019). 
interested in equivalent properties to different areas according to their race." ${ }^{35}$ The article examines how racial steering became sanctioned by the U.S. government prior to the FHA, and how it promoted de jure ${ }^{36}$ segregation. The history of racial steering and discrimination in the real estate profession informs why racial demographics associated with online real estate marketplaces are not an appropriate, and arguably illegal, space for such information.

\section{B. The Culture of Racial Segregation in the Real Estate Profession}

In The Color of Law, Rothstein discussed in detail federal, state, and local government policies that worked to keep African Americans ${ }^{37}$ oppressed and segregated from Whites in the post Reconstruction era. Jim Crow, ${ }^{38}$ sun down towns, ${ }^{39}$ racial zoning, ${ }^{40}$ redlining, ${ }^{41}$ blockbusting, ${ }^{42}$ and steering ${ }^{43}$ were all employed for the purpose of racial segregation. In the early twentieth century, the suppression of freed Blacks was relentless, and real estate agents played a major part in segregation efforts, due in part to institutional racism, racial fear, and private views of White supremacy.

35. Gladstone Realtors v. Vill. of Bellwood, 441 U.S. 91 (1979).

36. ROTHSTEIN, supra note 12 , at viii (defining de jure segregation and discrimination as segregation by law and public policy).

37. ROTHSTEIN, supra note 12, at XV-Xvii (illustrating Rothstein's use of this term).

38. Nat'l Fair Hous. Alliance, The Case for Fair Housing: 2017 Fair Housing Trends Report, 15 (2017) (stating laws passed throughout the South were used to create segregated residential communities and oppress Black people).

39. See generally, JameS W. LOEWEN, SUndOWn TOWNS: A HidDEN Dimension of AMERICAN RACISM 1-4 (2005).

40. RothSTEIN, supra note 12, at 45 (citing Buchanan v. Waverly, 245 U.S. 60, 81 (1917)) The fourteenth amendment provides for fundamental rights such as freedom to contract. Id. This underlying principle used in business deals was applied to racial zoning ordinances that attempted to interfere with the right of a property owner to sell to whomever they pleased, despite claims of discrimination and segregation in the sale of property. Id.; see ROTHSTEIN, supra note 12, at 5657. Racial zoning performed two major functions to promote segregated communities, keeping Blacks out of White neighborhoods and protecting white neighborhoods from deterioration by ensuring few industrial or unsafe businesses could locate within them. Id.

41. See Nat'1 Fair Hous. Alliance, supra note 38, at 17-18. Redlining was a practice created by Home Owners Loan Corporation in 1933. Id. The purpose was to stabilize housing markets after the Great Depression by dividing neighborhoods into categories and claiming that areas with minorities were high risk for mortgage lenders. Id

42. Id. at 24 (highlighting discriminatory practices of real estate practices). Prior to federal fair housing laws, agents engaged in "blockbusting" and "panic peddling" practices designed to scare White homeowners out of neighborhoods with rumors about "racial turnover." Id. The agents would then buy properties cheaply from Whites and sell them for higher prices to incoming Blacks. Id.

43. Id. at 34-36 (explaining racial steering). Real estate agents continue to play a role in the ongoing patterns of racial and ethnic segregation in the United States by "steering" home seekers to and away from neighborhoods with distinct racial compositions. Id. 
The National Association of Realtors ${ }^{\circledR}$ (formally known as the National Association of Real Estate Boards or NAREB ${ }^{44}$ ) was founded in 1908 in Chicago. The purpose of the association was "to unite the real estate men of America for the purpose of effectively exerting a combined influence upon matters affecting real estate interests." ${ }^{45}$ Membership in NAREB suggested real estate agents subscribed to a standard of professionalism in line with the association's Code of Ethics adopted in 1913. ${ }^{46}$ Involvement with NAREB provided agents with professional resources and access to national real estate trends and prominent market players. The influence NAREB had on the national housing market was extensive and directly contributed to the adoption of practices and strategies that explicitly discriminated against minorities. ${ }^{47}$ Until 1950, Article 34 of the National Association of Real Estate Broker's Code of Ethics stated: "[a] realtor should never be instrumental in introducing into a neighborhood a character of property or occupancy, members of any race or nationality, or any individual whose presence would clearly be detrimental to property values in that neighborhood." 48 The blatant subscription to steering practices as commanded in the code, in addition to government sanctioned segregationist policies, shaped discriminatory real estate practices that our nation still grapples with today.

The federal government built segregated homes during World War I, The Great Depression, and the pre and post-World War II era. ${ }^{49}$ After the Depression, The New Deal (a financial and housing reform effort created by the Franklin D. Roosevelt administration) ratified the 1934 National Housing Act; which chartered the Federal Housing Administration ("FdHA"). ${ }^{50}$ The FdHA was a collaborative effort between the federal government and private financial and housing industry leaders seeking to reform housing conditions

44. History, Nat'l Ass'n of Realtors, https://www.nar.realtor/about-nar/history (last visited Feb. 19, 2019) (describing name iterations through time). The National Association of Realtors ("NAR") was founded as National Association of Real Estate Exchanges in 1908. Id. In 1916 the group changed their name to The National Association of Real Estate Boards and was finally changed to NAR in 1972. Id.

45. Id.

46. Id.

47. See Code of Ethics, Nat'l Ass'n of Real Estate Boards, (last visited Feb. 21, 2019) https://webassets.inman.com/wp-content/uploads/2014/04/coe1928.pdf. (exhibiting codes of ethics adopted by member real estate agents at annual convention on June 22, 1928).

48. Id.

49. ROTHSTEIN, supra note 12, at 18-19 (describing time periods in which the federal government initiated construction of segregated public housing).

50. New Deal, ENCYCLOPEDIA BRITANNICA, https://www.britannica.com/event/New-Deal (last visited July 6, 2018). (explaining that The New Deal was "a domestic program of the administration of President Franklin D. Roosevelt, between 1933 and 1939, which took action to bring about immediate economic relief as well as reforms in industry, agriculture, finance, waterpower, labour [sic], and housing, vastly increasing the scope of the federal government's activities."). 
for working class (White) Americans struggling from the ruins of the Great Depression. ${ }^{51}$ To make the purchase of homes more affordable for middleclass renters the FdHA insured mortgage products to create home-ownership incentives. ${ }^{52}$ The FdHA insured banks, mortgage companies, lenders that covered $80 \%$ of purchase prices, offered twenty year loan terms, and loans that were fully amortized. ${ }^{53}$ The New Deal seemed noble on the surface; however, its policies and those of its legislative successors, generated homeownership opportunities and generational wealth for Whites and excluded Blacks entirely. ${ }^{54}$

To illustrate, The Home Owner's Loan Corporation ("HOLC"), the FdHA's predecessor, was created in 1933 to provide mortgage relief to home owners at risk of losing their homes through foreclosures. ${ }^{55}$ The HOLC hired real estate agents to help assess risk for mortgage lending by having agents collect information about the condition of homes and surrounding areas to determine if the communities would maintain their values. ${ }^{56}$ The hired agents made appraisals, and agents who were members of NAREB subscribed to the code of ethics to maintain segregation. ${ }^{57}$ From the data collected by agents, the HOLC created color-coded maps of metropolitan areas and color-coded low risk "safe" neighborhoods as green and high risk neighborhoods as red. ${ }^{58}$ Neighborhoods were marked red if Blacks lived in those communities, regardless of the economic stability of the Black residents. ${ }^{59}$

The FdHA, one of the chief proponents of racial segregation, discouraged banks from making any loans in urban neighborhoods and only insured White homeowners' mortgages if they lived in all-White neighborhoods into which there was little danger of Blacks moving. ${ }^{60}$ The FdHA published an Underwriting Manual which required bank lenders to

51. John Kimble, Insuring Inequality: The Role of the Federal Housing Administration in the Urban Ghettoization of African Americans, 32 LAW \& SOCIAL INQUIRY 399, 402 (2007) (describing impetus for creation of Federal Housing Administration).

52. ROTHSTEIN, supra note 12, at 64 (describing FdHA initiatives to encourage home ownership by providing affordable loan products).

53. Id.

54. Id. at 19 (detailing racist FdHA policies segregating housing projects).

55. FDR and Housing Legislation, Franklin D. RoOsevelt PreSidentlal Libr. \& MUSEUM, https://fdrlibrary.org/housing (last visited Jul 6, 2018) (marking the creation of the Home Owner's Loan Corporation).

56. Id. at 64 (noting real estate agents were hired to make appraisals)

57. See Historic Report, Nat'l Ass'n. of Realtors, https://www.nar.realtor/membership/ historic-report (last visited Jul 8, 2018) (charting real estate agents who were members of NAREB). Membership of NAREB from the 1930s to the 1960s ranged roughly between 10,500 to 91,000 agents. Id.

58. ROTHSTEIN, supra note 12, at 64.

59. Id.

60. Id. at 75 (describing rejection of funding for projects near Black communities). The government funded builders to mass-produce all White suburbs, and exodus from cities fueled by propaganda campaigns directed at white middle-class families. $I d$. 
keep the racially color-coded maps produced by the HOLC in "City Survey Files." 61 One of the FdHA's first published Underwriting Manuals explicitly promoted racial segregation by stating that, "[i]f a neighborhood is to retain stability it is necessary that properties shall continue to be occupied by the same social and racial classes." 62 The FdHA was also concerned with preventing school desegregation. Its manual warned that if children "are compelled to attend school where the majority or a considerable number of the pupils represent far lower level of society or an incompatible racial element, the neighborhood under consideration will prove far less stable and desirable than if this condition did not exist." $" 63$

The extent to which the FdHA implemented segregationist policies in their manual and loan guarantee products is beyond the scope of this article. However, reflecting on the impact the government had in shaping a segregated America is essential. Racist FdHA policies, federal funding for mass production of all White suburbs, and endorsement of segregation by real estate professionals, provides the necessary context for how state and private action afflicted an entire nation that created lasting repercussions. ${ }^{64}$ The U.S. Commission of Civil Rights summed up the reality of the racial divide in residential housing by stating, the "housing industry, aided and abetted by Government, must bear the primary responsibility for the legacy of segregated housing ... Government and private industry came together to create a system of residential segregation."

Although the Civil Rights Act of 1866 intended for Black Americans to have the same property rights afforded to White citizens, discrimination by both state and private actors never ceased. As noted above, in 1883 the Supreme Court rejected the congressional interpretation of its power to enforce the Thirteenth Amendment, stating that while it is proper to abolish "all badges and incidences of slavery" the 1866 Act does not include exclusion from housing markets as a badge or incidence of slavery, making the 1866 Civil Rights nearly obsolete for the next century. ${ }^{66}$ Consequently, most low income Black citizens were herded into ghettos and substandard living conditions. Some Black Americans with resources, and White integrationists, used the courts to obtain whatever justice they could. The Jones v. Mayer ${ }^{67}$ decision was one successful effort, along with the enactment

61. Kimble, supra note 51 , at 405 .

62. Fed. Hous. Admin., Underwriting Manual: Underwriting and Valuation PRocedure Under Title II OF THE NATional Housing ACt II 937 (1938).

63. Id. at 951 (quoting language from FdHA manual).

64. ROTHSTEIN, supra note 12, at 75 (summarizing government's commitment to segregated housing).

65. Id. (quoting conclusion by the 1973 U.S. Commission on Civil Rights).

66. Id. at viii-ix (describing the scope of the 1866 Civil Rights Act prior to 1968).

67. Jones v. Mayer, 392 U.S. 409, 412 (1965) (upholding the claim of an interracial couple 
of the FHA in 1968, which became and is still the central authority used by complainants to fight racial discrimination.

\section{The Prevalence of Steering: Social Science and Empirical Studies}

Since the enactment of the FHA, one would assume rates of racial steering and discrimination in housing transactions has decreased significantly. In most respects, explicit discrimination against minorities is less likely to occur; however, less obvious forms of discrimination are common. According to a 2012 study by the Department of Housing and Urban Development ("HUD"), which compared treatment between White, Black, Hispanic, and Asian homebuyers, results showed that agents significantly favored White testers over equally qualified Black and Asian testers. ${ }^{68}$ Black and Asian homebuyers were shown significantly fewer homes than equally qualified Whites, and agents offered Black and Asian homebuyers less information and assistance than equally qualified Whites. ${ }^{69}$

A comprehensive fair housing study was published in $1990 .^{70}$ In the study, approximately forty fair housing audits were conducted in Cincinnati, Ohio, and Memphis, Tennessee, which investigated six major real estate companies between 1983-1987 (15 years after the FHA was enacted). ${ }^{71}$ The study revealed that all agencies were found to have engaged in some sort of steering. ${ }^{72}$ George Galster evaluated the study and discussed forms of steering that took place, differences in treatment between White and minority subjects, and results. ${ }^{73}$ Galster notes that there are certain limitations to the test methodology; however, he concludes that agent actions do promote segregation. ${ }^{74}$ Some limitations of the study include the fact that the real estate firms audited were not randomly selected, audit scenarios involved smaller regions within the larger metropolitan housing markets, and therefore steering likely varied by community within metropolitan areas. ${ }^{75}$ Galster suggests the findings should be treated as "descriptive of the practices of real

against the Alfred H. Mayer Company for refusing to sell property to Jones strictly because he was black).

68. Margery Austin Turner et al., Housing Discrimination Against Racial and Ethnic Minorities 2012 xvii, 55 (2013), http://www.huduser.org/portal/Publications/pdf/HUD-514_ HDS20 12.pdf.

69. Id.

70. George Galster, Racial Steering by Real Estate Agents: Mechanisms and Motives, 19 REV. BLACK POL. ECON. 39 (1990).

71. Id. at 40 (identifying locations of audit study).

72. Id. at 39 (noting brief conclusion of study).

73. Id. at 40 (describing objective of research report).

74. Id. at 44 (diagraming steering in Table 1: Incidence of Steering, by Type).

75. Galster, supra note 70, at 58-59 (citing limitations of the study). 
estate firms in two metropolitan areas that often steer."76 Despite these limitations, it is reasonable to conclude agents continue to steer despite its illegality. ${ }^{77}$ Agents from the six real estate firms engaged in some sort of steering during at least one-half of the audited transactions, on average. ${ }^{78}$ Further, steering was perpetrated not only by showing houses in distinct locational patterns on the basis of race, but also by commentary about schools and neighborhoods directed almost exclusively to White testers, which tended to encourage them to select predominantly White neighborhoods. ${ }^{79}$

According to the study, in one of the metropolitan cities audited, steering that promoted segregation occurred $65 \%$ of the time through commentary (when agents give White auditors more favorable information about predominately White communities and less favorable information about racially mixed or predominately Black communities). ${ }^{80}$ About $46 \%$ of exchanges between real estate agents and auditors that related to the topic of school districts showed actions that promoted segregation. ${ }^{81}$ Black auditors were not necessarily limited to their geographic concentration, they were also shown homes in predominantly White areas, especially if requested. ${ }^{82}$ However, Blacks were shown significantly smaller fractions of homes in predominantly White areas, and significantly larger fractions of homes in mixed and predominantly Black areas. ${ }^{83}$ These "patterns persisted regardless of the geographic definition of area chosen: census block, census tract, school district, or community." 84 As noted by Galster's comments about the limitations of study methods, the results of the study should not be used to make generalizations about the incidence or magnitude of steering nationally or in metropolitan-areas, rather they speak to incidences of steering in the specific areas tested. ${ }^{85}$

Galster points out that his findings are consistent with his hypothesis that real estate agents steer in order to perpetuate "segregated housing markets buffered by a zone of racially transitional neighborhoods." 86 A system maintaining transitional markets improves the sales commission income of all agents because it intensifies the racially motivated turnover of housing in impermanent markets, and consequently, through a successive

\footnotetext{
76. Id. at 59 (citing limitations of the study).

77. $I d$.

78. Id. (expanding on conclusions about steering).

79. Id. (illustrating the use of coded language by agents).

80. Id. at 43 (discussing pro-segregation tactics).

81. Id.at 44 (displaying percent segregation by school district).

82. Id. at 59 (reiterating auditors were shown requested homes).

83. Id. (demonstrating steering of Black auditors).

84. Id. (underscoring fewer housing options for Blacks across geographic definitions).

85. Galster, supra note 70, at 59 (limiting scope of findings).

86. Id. at 59-60 (quoting hypothesis).
} 
chain of moves in metropolitan areas. ${ }^{87}$ Galster suggests that policy should focus on eliminating the economic interest in steering by bolstering testing as a form of deterrence or engage in pro-integrative marketing and housing initiatives. ${ }^{88}$ Galster made these two proposals in 1990 when his work was published. According to a 2000 HUD study based on thousands of paired tests in dozens of metropolitan areas, "[g]eographic steering on the basis of neighborhood racial composition appears to have increased significantly between 1989 and 2000." ${ }^{\prime 89}$ Despite continued testing efforts, steering by real estate agents still occurs using similar tactics as those identified in Galster's study a decade earlier.

In another study conducted during the summer and fall of 2000 , fair housing organizations conducted 4,600 paired tests across 20 metropolitan areas nationwide..$^{90}$ This report replicated a 1989 paired test study, compared results, and the comparison provided, at the time, the most complete analysis available about the persistence of housing market discrimination against Black and Hispanic home seekers. ${ }^{11}$ Though the study found that incidences of discrimination in rental markets and owner-occupied housing decreased significantly from 1989 to 2000 , discrimination against Hispanics in rental markets persisted. ${ }^{92}$ Also, despite the fact that discrimination against Blacks and Hispanics declined in regards to most measures tested (such as unit availability, unit inspection, rent prices, and follow up contact by agents, etc. ${ }^{93}$ ) the incidence of Blacks in the sales market being steered toward predominantly Black neighborhoods increased substantially between 1989 and $2000 .^{94}$

The study surmises that certain shifts, such as changes in social attitudes in regards to Blacks and Hispanics, licensing requirements for agents, and/or increased enforcement of fair housing laws, may have decreased incidences of blatant discrimination in housing markets by agents and sellers. ${ }^{95}$ However, the data in the study pointing to increased steering against Blacks to predominantly Black communities strongly suggests that the existence of underlying racial biases against people of color manifests in

87. Id. (explaining hypothesis).

88. Id. at 60 (proposing recommendations based on hypothesis)

89. Margery Austin Turner et al., Discrimination in Metropolitan Housing Markets: National Results from Phase I HDS 2000, Urban Institute, 3-12 (2002), https://www.urban.org/sites/ default/files/publication/60776/410821-Discrimination-in-Metropolitan-Housing-Markets.PDF.

90. Stephen L. Ross \& Margery Austin Turner, Housing Discrimination in Metropolitan America: Explaining Changes between 1989 and 2000, 52 SOCIAL PROBLEMS 152 (2005) https://www.jstor.org/stable/10.1525/sp.2005.52.2.152. (introducing parameters of study).

91. Id. at 176 (noting breadth of study).

92. Id. at 173-74 (highlighting continuation of discrimination against Hispanics)

93. Id. at 166 (depicting statistics in Table 3).

94. Id. at 175 (highlighting increase in anti-Black steering).

95. Id. at 174 (proposing theories to explain decrease in discrimination). 
more subtle ways. $^{96}$ These subtleties, according to the Housing Discrimination Testing Program (HDTP) ${ }^{97}$ at Suffolk University Law School, are referred to as "discrimination with a smile." Discrimination with a smile frames the issue faced today among many home seekers protected under federal and state fair housing laws in both rental and sales markets. The issue of subtle discrimination highlights one of the many problems with real estate websites using demographic information of school children. Historically, school quality and demographics have been used as coded language by agents to steer home buyers into or away from certain neighborhoods based on race. Owing to this past, one can reasonably deduce that race information displayed on websites, created in large part as a tool for real estate agents, elicits a similar bigoted purpose or at the very least, an analogous outcome-steering.

\section{The FHA Now - Relevant Laws and Steering in Online Mediums}

Fair housing laws created the initial enforcement mechanism needed in order to prevent real estate agents from endorsing segregation. In the past, real estate professionals segregated communities with more overt behaviors and steering laws reflected the prevalence of this more explicit person-toperson culture. However, blatant steering of homebuyers both in person and online is no longer as common a practice. With the advent of the internet and widespread use of real estate marketplaces, agents are less directly engaging in steering. Rather, the potential to steer homebuyers away from certain communities is more nuanced. Real estate websites have published race and ethnicity data of school children online by displaying the information within school ranking graphs. Why race and ethnicity data have been displayed at all is a question that must be examined within the historical context of racial steering cases. Due to this context, a legal prohibition to posting race data linked to real estate listings should be explicitly established.

Whether intentional or not, these websites have created an online space that enables racial steering on a massive scale. As a nationwide advertising tool, it is necessary for these online spaces to adhere to the same

96. Id. at 175-176 (explaining manifestations of implicit and subtle discrimination).

97. See Housing Discrimination Testing Program, SufFolk Univ. L. SCHOOL, https://www.suffolk.edu/law/academics-clinics/clinics-experiential-opportunities/housing-discrimi nation-testin g-program. (last visited Feb. 21, 2019). Id.

98. Jenny Rollins, Discrimination with a Smile, DigBoston. https://digboston.com/discrim ination-with-a-smile/ (last visited 02/04/2019) (In an interview with HDTP's Assistant Director, Jamie Langowski, she explains that transgender and gender non-conforming testers experienced subtle discrimination commonly referred to as discrimination with a smile). See Housing Discrimination Testing Program, supra note 97. 
standards as real estate professionals who transact in person and advertise in print. However, current steering laws are limited in their reach to prevent new forms of steering in modern markets. The following few sections discuss the law of steering under the FHA, property advertisements past and present, and competing interests between fair housing laws and the desire for freedom of information on the internet.

\section{A. Steering under the Fair Housing Act}

The FHA unambiguously outlines numerous forms of unlawful discriminatory conduct, ${ }^{99}$ but does not specifically reference steering in the statutory language. Fortunately, the FHA has been liberally construed by courts ${ }^{100}$ to uphold the purpose of the Thirteenth Amendment to eradicate the evils of slavery. ${ }^{101}$ As a result of the FHA's broad interpretation, the practice of steering is viewed by courts to be a violation of the FHA because it has been so rooted in racial animus and contributes to segregation.

The broadly interpreted language under section 3604(a) of the FHA provides that it shall be unlawful: "“ $[\mathrm{t}]$ o refuse to sell or rent after the making of a bona fide offer, or to refuse to negotiate for the sale or rental of, or otherwise make unavailable or deny, a dwelling to any person because of race, color, religion, or national origin." 102 Case law has established that steering is prohibited by the portion of section 3604(a) which makes it unlawful to "otherwise make unavailable or deny, a dwelling to any person because of race." 103 The interpretation of the above language, to include steering as making a property unavailable, helped to set the foundation for courts to rule on what constitutes illegal steering.

As defined earlier, the Supreme Court first defined racial steering in Gladstone Realtors v. Village of Bellwood ${ }^{104}$ as "directing prospective home buyers interested in equivalent properties to different areas according to their

99. See 42 U.S.C. $\$ \$ 3604$ (a)-(f) (2019) Prohibited conduct includes: the refusal to rent, sell or negotiate housing, deny dwellings, set different terms, conditions or privileges for the rental of a dwelling, provide different facilities or housing services, falsely deny housing is available for inspection or rental, and deny access to services related to the renting of housing, et al., on the basis of protected classes.

100. Trafficante v. Metro. Life Ins. Co., 409 U.S. 205, 209 (1972) (holding that Congress intended to define standing broadly).

101. Jones v. Alfred H. Mayer Co., 392 U.S. 409, 438 (1968) (holding that Congress has the authority to enforce the Thirteenth Amendment through legislation).

102. 42 U.S.C. \$ 3604(a) (2019); See also Zuch v. Hussey., 394 F. Supp. 1028, 1047 (E.D. Mich. (1975).

103. Zuch, 394 F. Supp. at 1047-1048 (holding that when a real estate agent tries to influence the choice of a prospective home buyer based on race, whether on their own initiative or in response to the buyer, the agent discourages the prospective home buyer from purchasing a home in a particular area).

104. Gladstone Realtors v. Vill. of Bellwood, 441 U.S. 91 (1979). 
race." 105 Racial steering was also defined in Havens Realty Corp. v. Coleman ${ }^{106}$ as a practice by which real estate brokers and agents "preserve and encourage patterns of racial segregation in available housing by steering members of racial and ethnic groups to buildings occupied primarily by members of such racial and ethnic groups and away from buildings and neighborhoods inhabited primarily by members of other races or groups."107 To be clear, according to these definitions, racial steering is not a total refusal to sell or rent; rather, it is a practice that makes certain housing "unavailable" to individuals based on race. ${ }^{108}$

Both definitions indicate that steering occurs when real estate professionals try to alter or influence a homebuyer's decision on where to purchase or rent a home based on race. These definitions also suggest that intent to steer is required in order to violate the FHA. The Sixth Circuit in Heights Community Congress v. Hilltop Realty, Inc. clarified that:

$[T]$ o violate $\$ 3604(\mathrm{a})$, one looks to whether the statement or conduct would have an untoward effect on a reasonable person under the circumstances who is seeking housing and behind the statement or conduct to the intent of the agent. If a statement or act would have a discriminatory effect and is made with the intent to steer, it violates $\S 3604(a){ }^{109}$

These definitions were in large part fashioned as a result of blatant discriminatory practices by real estate professionals. And, broadly interpreting the FHA has proven vital in the struggle against racial steering caused by real estate agents in traditional office or in-person settings. ${ }^{110}$ Today, technology and the proliferation of home searches on the internet redefine what it means to steer in modern times, reaching legally uncharted territory for the Fair Housing Act. How agents steered in the past and in person, versus how steering manifests online, is a legal gray area and should be more closely examined.

105. Id. at 94

106. Havens Realty Corp. v. Coleman, 455 U.S. 363 (1982).

107. Id. at 366 note 1.

108. Schwemm, supra note at 32 , at ch $13, \S 5$ (defining practices that amount to steering).

109. Id. (citing Heights Community Congress, 774 F.2d at 139-41). In Heights, the Sixth Circuit disagreed with defendant's definition of steering. Id.

110. See Zuch, 394 F. Supp. 1028, aff'd, 547 F.2d 1168 (6th Cir. 1977). The case reiterates that each section of the Fair Housing Act should be liberally construed to accomplish its purpose. Id. Unlawful representations regarding entry or prospective entry into neighborhood of person(s) of particular race, color, religion, or national origin includes subtle forms of racial inducements to sell. Id. These representation may be unlawful even if race is not explicitly mentioned. See Civil Rights Act of 1968, § 804(e) and 42 U.S.C.A. $\$ 3604(\mathrm{e})$. 
Agents who use real estate websites as a tool to advertise listings do not have a direct influence on which locations homeowners decide to explore further. The display of race-based information embedded within a property listing's drop-down menu is not at the hands of real estate agents. Rather, the display of race-based information within property listings is at the hands online content providers who work for real estate websites. Based on the distance between agent action and the display of race-based information by websites, whether or not agents intend to influence decisions of consumers based on race is taken out of the steering analysis. This circumstance does not fit within current legal definitions of steering. Companies have created an avenue for online advertisements to include racial demographics in property listings, which is a discouraged practice in print ads and in-person. What constitutes steering under the FHA should be expanded to incorporate the effect race data linked to property listings has on the consumer.

Limiting access to race information is not the solution proposed in this article, as consumers can find racial demographics of communities in a multitude of locations, including official government web pages. The point of contention highlighted in this article is the unsolicited display of racial demographic data alongside property listings. Having race data matched to property advertisements is the functional equivalent of an agent stating to a homebuyer, without prompting, that the racial makeup of a local school is majority minority. Judges have grappled with the extent to which a real estate agent may communicate information about the racial makeup of a neighborhood without violating the FHA, assuming they are serving the interests of the consumer. ${ }^{111}$ Fair housing consent orders have established the position that unsolicited race information could violate the FHA. ${ }^{112}$ In contrast, in Zuch v. Hussey, ${ }^{113}$ the opinion of the Court focused on the salesperson's efforts to influence a customer's housing choice on racial grounds stating those efforts would violate $\$ 3604$ (a) regardless of whether they were undertaken "on his own initiative or in response to the buyer's initiative, [because] the agent either directly or indirectly discourages the prospective home buyer from purchasing a home in a particular area."114

111. Schwemm, supra note at 33 (citing Village of Bellwood v. Dwivedi, 895 F.2d 1521, 1529-34 (7th Cir. 1990)). The Fair Housing Act allows agents to serve, but not influence, customer preferences regarding racial makeup of neighborhoods. Id.; U.S. v. Saroff, 377 F. Supp. 352, 361 (E.D. Tenn. 1974) aff'd, 516 F.2d 902 (6th Cir. 1975) (holding good faith response to racial preferences of customers is not a per se violation of Fair Housing Act).

112. Id. at ch. 13, $\$ 7$ (citing Consent Decree at 5, United States v. Mabry, Civ. No. 73-J-150R (S.D. Miss. March 11, 1974)) (discussing use of Fair Housing information). "Information with respect to the racial composition of a particular area ... shall only be made available in response to a particular question concerning such racial composition." Id.

113. Zuch, 394 F. Supp. at 1028 .

114. Id. at 1048 . 
The above cases are based on the behavior of agents who interacted in-person with customers. Likewise, the legal definitions of steering are derived according to the actions of agents. If the conduct includes the vocalization of race information with or without prompting, or if the agent deliberately provides the information to steer customers based on race, the source of steering differs drastically to how steering manifests online. One segment of Hilltop Realty's steering analysis could apply to the online steering issue - that "a reasonable person" could infer the act of posting unrequested, race-based information by a real estate website company could have a discriminatory effect that impacts communities of color. However, proving that a real estate company had intent to steer by posting race information online is a challenge, which is why an alternative theory to traditional steering laws would be more feasible. Even so, the perpetuation of segregation as a consequence of race-based marketing remains. While consumers could use race data online for the purpose of purchasing a home in a more integrated community, the nation's geographic landscape suggests otherwise. America remains highly segregated and posting race data adjacent to real estate listings stifles the FHA's mission of integration. ${ }^{115}$

The following section examines the regulatory authority of the FHA as it relates to housing advertisements in both online and off-line forums.

\section{Discriminatory Advertising and the Fair Housing Act}

Section 42 U.S.C.A. $\$ 3604$ (c) of the FHA is an important provision that regulates how individuals involved in any real estate transaction may advertise for homes. The FHA prohibits individuals involved in the sale or rental of housing " $[\mathrm{t}] \mathrm{o}$ make, print, or publish, or cause to be made, printed, or published any notice, statement, or advertisement, with respect to the sale or rental of a dwelling that indicates any preference, limitation, or discrimination based on [a protected class] or an intention to make any such preference, limitation, or discrimination." "116 The policy implication behind this section of the FHA is to prevent entire classes of people from being discouraged from considering publicly advertised homes. ${ }^{117}$ Housing advertisements, created for the purpose of reaching large audiences, can have

115. Schwemm, supra note at 33, at ch. 13 § (explaining "steering"). Under 24 C.F.R. § 100.70(a), HUD's general definition of steering states "it is unlawful, on the basis of race to restrict or attempt to restrict the choices of a person by word or conduct in connection with seeking, negotiating for, buying or renting a dwelling so as to perpetuate, or tend to perpetuate, segregated housing patterns, or to discourage or obstruct choices in a community, neighborhood or development. Id. This definition suggests that it is limited to steering that perpetuates or tends to perpetuate segregated housing patterns. $I d$.

116. 42 U.S.C \$ 3604(c) (2019).

117. United States v. Hunter, 459 F.2d 205, 210-11 (4th Cir. 1972). 
a vast deterrent effect if its content indicates a discriminatory preference, such as "no section 8," "professionals preferred,"119 or "not deleaded."120 Discriminatory language in advertisements frustrates the FHA's mission of integration and access to housing and are prohibited in print and published form.

Fortunately, the Ninth Circuit in Fair Housing Council of San Fernando Valley v. Roommates.com, $L L C^{121}$ emphasized actions that are "unlawful when [conducted] face-to-face or by telephone, [] don't magically become lawful when [done] electronically online." 122 Case law related to $\S$ 3604 (c) is clear that using language in advertisements that state a discriminatory preference or intends to convey a discriminatory preference is illegal. ${ }^{123}$ There exists competing interests concerning content posted online between the FHA and CDA, which is discussed at more length in the following section; yet, the issue of using race statistics online by real estate marketplaces is one of first impression and begs the question whether the display of race-data alone constitutes a discriminatory preference prohibited by the FHA. As a frame of reference, the NAR has acknowledged that real estate agents should avoid offering comments about school districts and race information about communities as a best practice, which was likely prompted by past discriminatory use of such information. In another instance, one court ruled that symbols used in advertisements, such as Christian religious symbols, violate the FHA because they may have a deterrent effect on nonChristian worshipers. ${ }^{124}$ An analogous conclusion can be made regarding

118. See, e.g., Craigslist, Housing Post (Oct. 19, 2019) https://boston.craigslist.org/sob/apa/ $\mathrm{d} /$ brockton-two-bedrooms-apartment/6999873459.html, (depicting discriminatory preference for people without housing vouchers in advertisements on Craigslist.org); MASS. GEN. LAWS ch. 151B, $\$ 4$ (Source of income is a protected class in Massachusetts).

119. See, e.g., Craigslist, Housing Post (Oct. 19, 2019) https://monterey.craigslist.org/apa/d/ carmel-1-bedroom-1-bath-furnished/7001837006.html (depicting discriminatory advertisement posted in California for professionals on Craigslist.org).

120. See, e.g., Craigslist, Housing Post (Oct. 19, 2019) https://boston.craigslist.org/ nwb/apa/d/lawrence-spacious-2-bedrooms-1-bath/7002890601.html (depicting discriminatory preference for professionals in California); see MASS. GEN. LAWS ch. 111, § 189A (Massachusetts requires housing providers to make homes lead safe if a child under the age of six resides in the home).

121. Fair Hous. Counsel of San Fernando Valley v. Roommates.com, LLC, 521 F.3d 1157 (9th Cir. 2008).

122. Id. at 1164 .

123. Hunter, 459 F.2d 205 at 210-211 (holding that congressional prohibition of discriminatory advertisements was intended to apply to newspapers and other publishing medium); see also S. Comm. on Banking and Currency: Hearings on S. 1358, S. 2114 and S. 2280 before the Subcomm. on Hous. and Urban Affairs, 19th Cong. 383-384 (1967) (George Meany's testimony, complaining of discriminatory housing advertisements in newspapers).

124. Lotz Realty Co., Inc. v. U.S. Dept. Of Hous. \& Urban Dev., 717 F. 2d 929, 930-31 (1983) (The Anti-Defamation League, an organization dedicated to fighting anti-Semitism, was named as a defendant in a suit that arose out of Lotz's use of Christian images and slogans in its real estate 
race-data posted in online advertisements because the data can potentially deter homebuyers of a different race to communities that match their racial profile.

In contrast, courts have determined that affirmative marketing plans (AMPs) are not a violation of section 3604 (c) of the FHA. ${ }^{125}$ AMP's stem from collaborations between non-profit organizations and HUD for the purpose of promoting integrated communities and involve special outreach tactics targeting minority populations. ${ }^{126}$ In South-Suburban Housing Center v. Greater South Suburban Board of Realtors, ${ }^{127}$ the plaintiffs, a nonprofit corporation, contracted with brokers to conduct marketing outreach for homes located in a predominantly Black neighborhood in Chicago. The purpose was to attract White homebuyers and encourage integration. The appellate court concluded that the AMP directed at White homebuyers did not violate the FHA because the "marketing plan merely provided additional information to White homebuyers concerning properties they might not ordinarily know about nor consider, and involved no lessening of efforts to attract [B]lack home buyers to these same properties."128

AMPs and targeted advertisements were meant to integrate communities and exposed more individuals to areas they may otherwise not consider. AMPs, and most marketing campaigns of yesteryear, were printed in newspapers, published in housing periodicals, or posted on bulletin boards. As noted, today most home seekers start their search on the web by reviewing self-filtered property postings. While the FHA treats advertisements with a discriminatory preference the same in both print and online mediums, it is unclear if racialized graphs displayed within property listings would be considered a discriminatory preference under section 3604 (c).

advertising. Id. After receiving a protest about this practice, the League filed a complaint with the Department of Housing and Urban Development and the Virginia Real Estate Commission. The complaint was filed under the Fair Housing Act, 42 U.S.C. \$ 3604(c) (1977), and the Virginia Fair Housing Law, Va. Code Ann. $§ 36-88$ (1976 \& Cum.Supp.1983), both of which forbid housing discrimination based upon religion. $I d$. Both HUD and the Commission found reasonable cause to believe that Lotz's advertising violated fair housing law. $I d$.

125. S.-Suburban Hous. Ctr. v. Greater S. Suburban Board of Realtors, 935 F.2d 868, 884 (7th Cir. 1991).

126. S.-Suburban Housing Center v. Greater S. Suburban Board of Realtors, 713 F. Supp. 1068, 1075 (1988) (detailing the creation of Voluntary Affirmative Marketing Agreement "VAMA." HUD and NAR executed a VAMA, defining affirmative marketing "as a program to inform the minority community of the homes listed for sale or rent by Realtors, of the services offered ..., and of the availability of these homes and services to all buyers without regard to race, color, religion, sex or national origin").

127. Id.

128. Greater S. Suburban Board of Realtors, 935 F.2d at 884 (declaring AMPs uphold the purpose of the FHA by promoting integration). 
The following section discusses the interplay between the Communications Decency Act, which determines the scope of immunity enjoyed by online forums, and the FHA.

\section{The Communications Decency Act}

When discussing restriction of information on the internet, the CDA must be explored. Section 230 of the CDA immunizes providers of interactive computer services against liability arising from content created by third parties: "[n]o provider... of an interactive computer service shall be treated as the publisher or speaker of any information provided by another "information content provider." "129 Essentially, there is a difference between online services that manage content (content provider) on their sites versus those that act more as a store house of information (service provider). Under the CDA, the grant of immunity applies only if the "interactive computer service provider" is not also an "information content provider," which is defined as someone who is "responsible, in whole or in part, for the creation or development of offending content." 130 Real estate websites appear to function more as a content provider than a service provider, and are likely not immune under the CDA. The litigation strategy proposed in Section III necessitates real estate websites be exempt from CDA protection. The below analysis sheds light on why real estate websites are likely exempt.

\section{i. Origins of the CDA}

The CDA was initially created to prohibit obscene or indecent material from reaching children on the internet. ${ }^{131}$ Opponents of the CDA argued it was government overreach, which triggered Congressmen Christopher Cox and Ron Wyden, to draft an amendment to the CDA which later became known as Section $230 .^{132}$ The objective of the CDA was to "remove the disincentive to police content and to encourage the dissemination of words and ideas on the Internet."133 The CDA was created as a response to Stratton Oakmont, Inc. v. Prodigy Services, Co., which was

129. 47 U.S.C. $\S 230$ (c) (2019).

130. Id. at $\S 230(\mathrm{f})(3)$.

131. Brief of Internet, Business, and Local Government Law Professors as Amici Curiae Supporting the Respondents at 7, Homeaway.com \& Airbnb, Inc. v. City of Santa Monica, Nos. 2:16-cv-06641-ODW, 2:16-cv-06645-ODW (9th Cir. May 23, 2018).

132. Id. at 6.

133. Joey On, The Overexpansion of the Communications Decency Act Safe Harbor, 35 Hastings Comm/EnT L.J. 455, 458 (2013) (citing James D. Shanahan, Rethinking the Communications Decency Act: Eliminating Statutory Protections of Discriminatory Housing Advertisements on the Internet, 60 FED. COMM. L.J. 135, 139 (2007)). 
decided prior to the drafting of Section 230. The Stratton court emphasized the difference between passive and active service providers. The court distinguished between distributors that were "passive receptacle[s] or conduit[s]," of information and providers that "exercise ... editorial control and judgement."134 As such, print media would be within the bounds of publisher liability if they attempted to filter, edit, or sort content because it was considered an act of editorial control. ${ }^{135}$ Editing web content, under this ruling, exposed online service providers to more liability as opposed to those who left all information posted, untouched. ${ }^{136}$ Another consequence of the Stratton ruling was that it limited incentives for service providers to selfpolice their websites for illegal third-party content. ${ }^{137}$ Congress responded to the Stratton ruling by creating the Communications Decency Act of 1996 to establish a safe harbor for service providers by absolving them from liability arising from content generated by third parties. ${ }^{138}$

Though the CDA is intended to protect internet freedom, when examining Section 230 more closely, it is actually limited in scope because the substantive text of the statute contains requirements that limit its application. ${ }^{139}$ To clarify, the language in Section 230 is restricted to preventing a "provider or user of an interactive computer service" from being "treated as the publisher or speaker of any information" that is exclusively "provided by another content provider." 140 The Ninth Circuit interpreted Section 230 and determined that publishing amounts to "reviewing, editing, and deciding whether to publish or to withdraw from publication third-party content." "141 Based on this reading, the law targets only "certain internetbased actors from certain kinds of lawsuits." 142 The statute, as discussed by the Court in Roommates.com, $L L C$, gave no protections for online content that was created by a website operator or developed-in whole or in part by the website operator. ${ }^{143}$ And, the CDA gives no protection for actions or

134. Stratton Oakmont, Inc. v. Prodigy Servs. Co., N.Y. Sup. Ct. 1, 3 (1995) (identifying actions constituting editorial control); see also Defterderian, Varity, Fair Housing Council v. Roommates.com: A New Path for Section 230 Immunity, 24 BERKELEY TECH. L.J. 565, 566 (2009) (distinguishing acts that expose service providers to publisher liability).

135. Defterderian, supra note 134, at 566 (emphasizing reach of Stratton ruling).

136. Id. (noting consequences for exerting editorial control).

137. $I d$. (noting additional consequences for exercising editorial control).

138. Id. (explaining the motivation for the creation of the CDA).

139. Brief of Internet, Business, and Local Government Law Professors as Amici Curiae Supporting the Respondents at 9, Homeaway.com \& Airbnb, Inc. v. City of Santa Monica, Nos. 2:16-cv-06641-ODW, 2:16-cv-06645-ODW (9th Cir. May 23, 2018).

140. 47 U.S.C. $\$ \$ 230(c)(1),(f)(3)$ (2019).

141. Barnes v. Yahoo!, Inc., 570 F.3d 1096, 1102 (9th Cir. 2009).

142. Brief of Internet, Business, and Local Government Law Professors as Amici Curiae Supporting the Respondents at 4, Homeaway.com \& Airbnb, Inc. v. City of Santa Monica, Nos. 2:16-cv-06641-ODW, 2:16-cv-06645-ODW (9th Cir. May 23, 2018).

143. Roommates.com, LLC, 521 F.3d at 1162 (citing 47 U.S.C. $\$ 230(f)(3)$ ). 
omissions that are unrelated to its publishing decisions. ${ }^{144}$ The importance of these limitations, as they relate to real estate websites, are described in the following sections.

\section{ii. Cases Interpreting CDA}

One of the first cases to interpret the scope of immunity provided by Section 230 of the CDA was Zeran v. America Online. ${ }^{145}$ The Zeran court ultimately extended the protections of the CDA and held interactive service providers are not liable for defamatory online postings by third parties. The Zeran court created a three-part analysis ${ }^{146}$ for courts to identify in which circumstances a service provider would be immune from liability for the content of third-parties. The third prong of the test requires that defendants who develop or create any of the content online places them outside of the protections of the CDA.

The Court in Roommates.com interpreted the word "development" in the third prong of the Zeran test to mean that website managers who "materially contribute" to the illegality of content are not protected by the CDA. ${ }^{147}$ Further, Roommates.com highlights the fact that websites can be both service providers and content providers at the same time. ${ }^{148}$ If a website "passively displays content that is created entirely by third parties, then it is only a service provider with respect to that content." Likewise, if a website creates portions of content itself, "or is 'responsible, in whole or in part' for creating or developing, the website is also a content provider." 149

\section{iii. Applying CDA to Real Estate Websites}

While the CDA sought to promote internet freedom for public access to information, it has also resulted in collateral consequences by enabling internet companies involved in the marketing of real estate to advertise in ways that may lead to steering and discrimination. ${ }^{150}$ The behavior of

144. Barnes, 570 F.3d at 1105; Accord Doe v. Internet Brands, Inc., 824 F.3d 846, 851 (9th Cir. 2016) (finding that a message board operator cannot be required to "monitor postings" or "remove any user content").

145. Zeran v. America Online, Inc., 129 F.3d 327 (4th Cir. 1997)

146. Id. at 567 (Zeran's three-prong test requires: 1) a defendant must be a provider or user of an interactive computer service; 2) holding a defendant liable would treat it as a publisher or speaker of third-party content; and 3) the defendant must not have developed or created, in whole or in part, the content at issue).

147. Roommates.com, LLC, 521 F.3d at 1163.

148. Id. at 1162 .

149. Id.

150. Id. at 1187 (citing Chi. Lawyers' Comm. for Civil Rights Under the Law, Inc. v. Craigslist, Inc., 461 F. Supp. 2 d 681 (N.D. Ill. 2006)); see also Housing Discrimination Complaint, 
housing consumers has changed drastically since 1996 when Section 230 of the CDA was first enacted. The widespread use of real estate websites by consumers amplifies the negative consequences of using race data as a marketing tool. In light of the widespread use of websites like Zillow.com, it is important to understand their position within the context of the CDA. Based on the Roomates.com analysis, real estate websites perform more closely to managers of content rather than publishers of content, and are therefore, more likely to be excluded from CDA protections. The exclusion of real estate websites from CDA protection is a necessary first step if the litigation strategy proposed in the final few sections of the article are to survive.

In Roommates.com, the Court held that the filter functioning and email notification system did not fall within the protections of the CDA because emails to subscribers were sorted according to discriminatory criteria. ${ }^{151}$ Users were steered to like users based on preferences and personal characteristics that were elicited from drop-down questions created by website developers. ${ }^{152}$ The Court noted that limiting the information a subscriber can access based on that subscriber's protected status violates the Fair Housing Act and state housing discrimination laws. ${ }^{153}$ The Court compared the online practice to a real estate broker stating to a client " $[\mathrm{s}]$ orry, sir, but I can't show you any listings on this block because you are [gay/female/black/a parent]." ${ }^{154}$ The Court concluded that if such screening criteria were unlawful in person, they see no reason why Congress would have allowed for such conduct online. ${ }^{155}$ Likewise, as explained in Part B of this section, race information provided to a home seeker by a real estate agent in person, without prompting or by request, straddles the line of violating the FHA,${ }^{156}$ and is a practice now discouraged by the NAR. So, providing race information linked to property listings to consumers online, without prompting or by request, also straddles the line of violating the FHA via segregative effect theory.

The drop-down functions that forced Roommates.com outside of the protections of the CDA are more conspicuous than the operations of Zillow and similar websites. Even so, real estate website operators create portions

Assistant Sec'y of Fair Hous. \& Equal Opportunity v. Facebook, Inc., No 01-18-0323, 2, (listing FHA violations), available at https://www.hud.gov/sites/dfiles/PIH/documents/HUD_01-180323_Complaint.pdf (last visited Feb. 22, 2019).

151. Id. at 1167 .

152. Id.

153. Id.

154. Id.

155. Id.

156. See generally Part B. The analysis depends on whether or not the agent intended to steer the consumer based on race. See Heights Cmty. Cong., 774 F.2d. at 139-41. 
of content that more align them with content managers than passive service providers. For example, when Zillow and other websites construct advertisement platforms that embed charts with race data, they have developed content by virtue of intentional design. To illustrate, Zillow has used school information created by third-party providers, like Greatschools.org and NICHE, and have changed layouts of the information to match the design of their webpages and to fit within expandable drop downs. The Zillow charts differ visually from the graphs provided on Greatschools.org, indicating that Zillow manipulated the graphical information to fit their style format. Also, Zillow routinely changes data sets by making intentional decisions about what data to display, manage, and manipulate according to their style guides and proprietary decisions, ${ }^{157}$ which sometimes include student race and ethnicity data, neighborhood demographics detailing familial status, first time homeowner information, crime statistics, income ranges, and more.

Zillow's company is also more aligned with content managers than passive service providers because of the array of services they provide to both consumers and real estate professionals. Zillow does not merely connect consumers looking for homes with agents, they also engage in brokering activities of their own. Zillow acts as an agent by selecting homeowners, flipping their homes, and reselling these homes on their website. The extent of Zillow's services are laid out on the website:

Zillow Group owns and operates a portfolio of the largest real estate and home-related brands on mobile and the web. The company's brands focus on all stages of the home lifecycle: renting, buying, selling and financing. Zillow Group is committed to empowering consumers with unparalleled data, inspiration and knowledge around homes, and connecting them with great real estate professionals. In addition, Zillow Group provides a comprehensive suite of marketing software and technology solutions to help real estate professionals maximize business opportunities and connect with millions of consumers. Zillow Offers ${ }^{\mathrm{TM}}$ provides homeowners in some metropolitan areas with the opportunity to receive offers to purchase their home from Zillow. When Zillow buys a home, it will make

157. Teke Wiggin, Where Did Zillow Demographic Data Go?, InMan (Jan. 8, 2015), https:// www.inman.com/2015/01/08/where-did-zillows-demographic-data-go/. Inman interviewed Amanda Woolley, Zillow representative, who stated the "listing portal is 'constantly evolving all aspects of our offering-including our look, feel and functionality-to better meet the needs of consumers." Id. 
necessary updates and list the home for resale on the open market. ${ }^{158}$

The brokering activities alone demonstrate Zillow's capacity and engagement with website visitors that extend far beyond the category of passive conduits who only provide information to consumers. As a business that has shaped the real estate market, many of the services Zillow provides fall outside sphere of traditional publishing activities. The management and manipulation of data sources based on business strategy, and the brokering of transactions, bring Zillow, and similarly managed real estate websites, outside the realm of immunity under the CDA.

\section{Real Estate Websites and the Modern Market}

\section{A. The Home Buyer}

Zillow Group and the NAR conduct studies by disseminating questionnaires that gauge what consumers look for when buying a home, home buying trends, and use the information to guide their marketing strategies. ${ }^{159}$ Zillow Group conducted a comprehensive study of the housing market and home buying trends in 2018 leading to the Consumer Housing Trends Report. ${ }^{160}$ The study was conducted between April 25 and June 10 of $2018 .{ }^{161}$ The researchers conducted a survey and gathered information from 13,439 individuals who self-identified as key household decision-makers. ${ }^{162}$ Approximately 3,000 individuals interviewed were buyers who moved in the past 12 months to a primary residence purchased within the past year. ${ }^{163}$ According to Zillow Group's results, millennials ages 24 to 38 are heavily influenced by the age of technology and "Google culture," which allows them

158. Welcome to Zillow Group Investor Relations, ZILLOW GROUP, http://investors.Zillow Group.com/index.cfm (last visited Feb. 22, 2019).

159. See Consumer Housing Trends Report 2018, Zlllow Group, 4 (2018), https://w p.zillowstatic.com/38/ZGReport2018_Download-a27213.pdf. "The Zillow Group Consumer Housing Trends Report 2018 offers insight into those behaviors, aspirations and decisions, shining a light for consumers and industry experts on the who, what, where, when, how and why of home in America." Id. The "National Association of Realtors ${ }^{\circledR}$ does research on a wide range of topics of interest to real estate practitioners, including market data, commercial, international, home buying and selling, NAR member information, and technology. Use the data they contain to improve your business through knowledge of the latest trends and statistics." Research Reports,

NAT'L ASS'N OF REALTORS, https://www.nar.realtor/research-and-statistics/research-reports (last visited Feb. 22, 2019).

160. Consumer Housing Trends Report 2018, ZILLOW GROUP, 4 (2018), https://wp.zillow static.com/38/ZGReport2018_Download-a27213.pdf.

161. Id. at 8 (stating start and end dates of study).

162. Id.

163. Id. 
to do their own independent housing research. ${ }^{164}$ Even still, the majority of these buyers view agents as strategic partners with market expertise. ${ }^{165}$ The report noted that buyers rely heavily on both online tools (79\%) and agents (74\%) to purchase their homes. ${ }^{166}$ NAR also conducts an annual survey to gather profile information of homebuyers nationwide. ${ }^{167}$

According to their most recent survey, $44 \%$ of recent buyers looked online first for property sales, while $17 \%$ of buyers first contacted a real estate agent. ${ }^{168}$ Online websites were the most useful sources of information for about $88 \%$ buyers according to NAR. ${ }^{169}$ Among buyers who used the internet during their home search, $87 \%$ found photos and $85 \%$ found detailed information to be the most useful. ${ }^{170}$ While some percentages differ between Zillow Group's and NAR's surveys, one trend is clear - one of the first steps many homebuyers take when searching for a new home is to look up active listings on real estate websites.

The median age of homebuyers over the last twelve months was 41 and they were overwhelmingly Caucasian/White $(76 \%) .{ }^{171}$ White homebuyers substantially outnumbered Hispanic/Latino buyers (10\%) and African-American/Black buyers $(5 \%){ }^{172}$ Considering the history of discrimination described in Section I, the lower numbers of Black and Hispanic homebuyers underlines the harmful impact systemic racism in the

164. Id. at 47 .

165. Id.

166. Id. at 6.

167. Jessica Lautz, et al., 2018 Profile of Home Buyers and Sellers, Nat'l Ass'n of Realtors, 5 (October 2018), https://www.nar.realtor/sites/default/files/documents/2018\%20HBS\%20H ighlights.pdf. Among nearly all generations of home buyers, the first step taken was to look online for properties, except for buyers 71 years and older who contacted a real estate agent first. See also Jessica Lautz, et al., 2017 Home Buyer and Seller Generational Trends Report, Nat'l Ass'n of Realtors, 6 (2017), https://www.nar.realtor/sites/default/files/reports/2017/2017-home-buyerand-seller-generational-trends-03-07-2017.pdf. As a result of an internet home search, buyers most often walked through the home that they viewed online. See also Jessica Lautz, et al., 2018 Home Buyer and Seller Generational Trends Report, Nat'l Ass'n of Realtors, 7 (2018), https://www.nar.realtor/sites/default/files/documents/2018-home-buyers-and-sellers-generati onal-trends-03-14-2018.pdf. Buyers 51 years and younger saw the exterior of homes because of searching online for properties. The most important website feature was photos for nine in ten buyers under the age of 62 . Id. at 51 .

168. Jessica Lautz, et al., 2018 Profile of Home Buyers and Sellers, supra note 167, at 142 (discussing online home searches). NAR found that a total of 7,191 responses out of 155,250 surveys were received, giving NAR a $4.6 \%$ response rate. $I d$. Respondents were individuals who bought a home between July 2017 and June 2018. Id. at 7 .

169. Id. at 7.

170. Id.

171. Consumer Housing Trends Report 2018, ZILLOW GRouP, 51 (2018), https://wp.zillow static.com/38/ZGReport2018_Download-a27213.pdf (illustrating a graph in B-1 percentage of homebuyers by age and race).

172. Id. (displaying percent of Black and Hispanic home buyers). Asian/Pacific Islander buyers at $6 \%$, others at $3 \%$. Id . 
housing market has had on people of color over the last century. Another notable finding in Zillow Group's report centers on the significance of diversity when considering a neighborhood. According to the results, nearly half of the homeowners surveyed (45\%) indicated that racial diversity is "Not very or not at all important" to them, while approximately $23 \%$ indicated it was somewhat important and $35 \%$ indicated it was extremely or very important. ${ }^{173}$ According to the survey, younger generations tend to place greater importance on neighborhood diversity than older generations. ${ }^{174}$ These questions and responses highlight the fact that the racial makeup of a neighborhood is very much a consideration for buyers when looking for a home.

Whether buyers are in the $55 \%$ who at least care somewhat about racial diversity, or are the $45 \%$ who do not value diversity at all or very little, information about racial demographics should be obtained and assessed via the buyers own independent research. Buyers are in the best position to assess the feel of a community and racial demographics for themselvesrather than making decisions based off underdeveloped race data linked to property listings. Race data provided in school ranking graphs can be misleading to the consumer. The graphs displayed on Zillow that portray the racial makeup of schools may reflect the schools to a certain degree, but the graphs are not comprehensive. The oversimplified data can mislead homebuyers who use school quality as a factor when choosing between one community or another.

The large majority $(76 \%)$ of homebuyers in the last year were White/Caucasian, $45 \%$ of homebuyers did not care to live in racially diverse neighborhoods, and our cities and suburbs are getting increasingly more segregated. ${ }^{175}$ Based on these statistics, it would be imprudent to think that race data linked to property listings online do not have a deterrent effect on a large portion of consumers. While race information may be viewed as valuable for individuals who choose to live in integrated communities, our geographic landscape suggests that many people are choosing to live in more racially homogenous areas.

173. Id. at 59 (illustrating in graph B-5 percent of homebuyers interested in diverse communities); see also Aaron Terrazas, Homeownership Aspirations: The Enduring and Evolving American Dream, ZILlow ReSEARCH (June 6, 2018), https://www.zillow.com/res earch/homeownership-american-dream-20476/ (explaining white homebuyers prefer to live in suburbs over African American and Latino homebuyers).

174. Id. (summarizing results from graph B-5).

175. Jenny Schuetz, Metro areas are still racially segregated but it's more complicated than "chocolate city, vanilla suburbs," BROOKINGS: THE AVENUE (Dec. 8, 2017), https://www.brook ings.edu/blog/the-avenue/2017/12/08/metro-areas-are-still-racially-segregated/ (blogging synopsis of poverty and segregation research). 


\section{B. How Agents Use Online Marketplaces}

The number of users who search online for homes is significant. The traffic of visitors coming across real estate marketplaces online are in large part why agents are so attracted to these platforms. Zillow increases the volume of business for agents because Zillow's webpages have massive exposure online. Zillow states the extent of their functionality, usefulness, and purpose on their "About" page:

Zillow is the leading real estate and rental marketplace dedicated to empowering consumers with data, inspiration and knowledge around the place they call home, and connecting them with the best local professionals who can help. []Zillow serves the full lifecycle of owning and living in a home: buying, selling, renting, financing, remodeling and more. It starts with Zillow's living database of more than 110 million U.S. homes - including homes for sale, homes for rent and homes not currently on the market, as well as Zestimate home values, Rent Zestimates and other home-related information. Zillow operates the most popular suite of mobile real estate apps, with more than two dozen apps across all major platforms. ${ }^{176}$

The company exclaims that it is built on the premise of data sharing so that consumers can be as educated as possible about their home buying process. The freedom to acquire information and ease of access to data is extremely valuable and this article does not suggest that censorship of race information is a solution to combat potential steering online. Licensed agents, who must abide by ethical standards per NAR membership requirements ${ }^{177}$ and legal standards under the FHA, advertise listings with an interface designed by Zillow. In the same way agents are strongly discouraged from offering racialized information in person and in print, ${ }^{178}$ so too should their online advertisements avoid race data attached to the listings, even if the data is generated by third-party companies. A basic understanding of user logistics between agents and real estate websites illustrate why separating race data from property listings is appropriate.

176. ZILLOW, https://www.zillow.com/corp/About.htm (last visited Feb. 8, 2019).

177. See generally CODE OF ETHICS, Nat'1 Ass'n of Realtors (2019), https://www.nar.re altor/about-nar/governing-documents/code-of-ethics/2019-code-of-ethics-standards-of-practice (displaying most recent ethical standards as of January 1, 2019).

178. Id. at $\S 10-3$ (stating no agent shall publish a discriminatory preference). 
Zillow requires real estate brokers to create a profile and submit a license identification number before publishing a listing on their website. Before Zillow acquired Trulia in 2015, ${ }^{179}$ agents used Postlets, an application for creating real estate listings, to post on websites like Trulia and Hotpads. ${ }^{180}$ Now, agents generate listings for Trulia, Hotpads, and Zillow by creating one profile on Zillow Group. ${ }^{181}$ As an agent, access to Zillow's marketing services on Zillow Group require the same license identification number noted above. Once access is obtained, the agent must enter property information in pre-designated fields, draft a property description, submit the posting, and Zillow's algorithms integrate the property information into their web interface by using the location of active listings to populate demographic data. The algorithms used to populate the demographic information suggests that Zillow's website is a content manager outside the protection of the CDA. The role of Zillow is specified in their terms of use policy, which explicitly states that Zillow has a real estate license in Texas but does not act as a broker on behalf of users and agents; ${ }^{182}$ furthermore, users must abide by certain standards for posting properties. ${ }^{183}$ Homeowners may also list their properties on Zillow and must prove ownership by brandishing a certificate or title of ownership and abide by similar terms of use and listings quality policies. ${ }^{184}$

One central function of Zillow is that it provides a platform to amplify agent listings by requiring agents to input information for property listings manually. Zillow's website supplements agent listings with statistics and demographic information, which has in the past included race information from third-party providers like Greatschools.org and NICHE, and is published on Zillow's property listing page. Some frequently recurring types of information displayed on real estate webpages, in addition to location details and photos, include building descriptions, market value analytics,

179. Zillow Inc., Unaudited Pro Forma Condensed Combined Fin. Info. Exhibit 99.2 (Feb. 17, 2015), available at https://www.sec.gov/Archives/edgar/data/1617640/0001 193125\15116051/d898414dex992.htm; Zillow Completes Acquisition of Trulia for \$2.5 Billion in Stock; Forms "Zillow Group" Family of Brands, ZLLLOw GrouP: MEDIA ROOM (Feb. 17, 2015), http://ZillowGroup.mediaroom.com/2015-02-17-Zillow-Completes-Acquisition-of-Truliafor-2-5-Billion-in-Stock-Forms-Zillow-Group-Family-of-Brands.

180. Luke Dery, ET AL., THE Zlllow/Trulia MerGer 6 (University of St. Thomas Minnesota, Opus College of Business), available at https://www.economist.com/sites/default/ files/team_lusteconomistcase.pdf (last visited Feb. 8, 2019).

181. Zillow Rental Manager: FAQ, ZILLOW (Apr. 2019), https://zillow.zendesk.com/hc/enus/articles/214861828-Zillow-Rental-Manager-FAQ. The frequently asked questions page informs agents that all postings can now be managed by creating an agent profile on Zillow. Id.

182. Terms of Use \& Privacy Policy, ZILlow, II 1 (Aug. 14, 2018), https://www.Zillow Group.com/terms-of-use-privacy-policy/terms-of-use/.

183. See Listings Quality Policy, ZILLOw (Aug. 2018), https://www.zillow.com/corp/ Quality.htm.

184. Id. at $\mathbb{1}$ 1(i) (discussing for sale by owner and for rent by owner policies). 
neighborhood characteristics, school data and statistics, accessibility and walkability metrics, and crime rates. The sources from which these metrics are created vary. For example, walkability metrics on both Zillow and Redfin are generated by a company known as Walk Score that rates walkability on a scale of 1-100. ${ }^{185}$ Redfin has obtained crimes statistics from Best Places, a company known for mining and packaging data for consumer use. ${ }^{186}$ Redfin, a leading competitor of Zillow, ${ }^{187}$ shares similar online features but has a different business model for using agents. Redfin employs real estate agents as their primary market experts who can also work in tandem with "independent associate agents" from a variety of local agencies. ${ }^{188}$ Zillow Group's application tends to focus on marketing for agents while Redfin offers marketing and hands-on services by hired agents.

Both models demonstrate a level of engagement with real estate agents that require property listings posted by agents to be held to the same standards under the FHA as listings posted in print mediums. Web applications using map-based technologies that require manual input from licensed agents should be treated no different than agents posting advertisements in local newspapers. Both mediums reach large audiences and both mediums are generated by real estate market professionals subject to the FHA.

\section{The Race Data}

Zillow Group, Redfin, and NAR provide home seekers with massive amounts of news, statistics, research, and reports related to consumer and real estate market trends. ${ }^{189}$ The wealth of information provided by these companies come from various sources such as United States Bureau of Labor

185. About Walk Score, WALK SCORE, https://www.walkscore.com/about.shtml (last visited Feb. 12, 2019). Walk Score is now part of Redfin. Id.

186. Best Places is a third-party company founded and operated by Bert Sterling. Meet the Best Places Team, Best PLACES, https://www.bestplaces.net/docs/team.aspx (last visited Feb. 12, 2019). The company analyzes data from numerous sources about people and places, and rates them for publication. Where Do We Get Our Data?, BESTPLACES, https://www.bestplaces.net/ docs/datasource.aspx (last visited Feb. 12, 2019).

187. See Evan Tarver, The 5 Best Alternatives to Zillow \& Trulia, INVESTOPEDIA: HOME OWNERSHIP (updated Apr. 17, 2019), https://www.investopedia.com/articles/markets/100215/ 5-best-alternatives-zillow-trulia.asp.

188. Find a Local Redfin Real Estate Agent, REDFIN, (updated Jan. 2019), https://www. redfin.com/real-estate-agents (detailing how Redfin works with scheduling coordinators, Redfin agents as experts, and contracts with independent associate agents).

189. See Zillow Research, ZILLOw, https://www.zillow.com/research/ (last visited Feb. 12, 2019); see also Real Estate News \& Analysis, REDFIN, https://www.redfin.com/blog/real-estatenews/ (last visited Feb. 12, 2019); Research and Statistics, Nat'l Ass'n of Realtors, https:// www.nar.realtor/research-and-statistics (last visited Feb. 12, 2019); News \& Insights, REALTOR.COM, https://www.realtor.com/news (last visited Feb. 12, 2019). 
and Statistics, United States Department of Education, and local government websites. However, school rankings displayed on real estate websites are commonly generated by third-party companies like aforementioned Greatschools.org, ${ }^{190}$ Niche.com, ${ }^{191}$ and SchoolDigger. ${ }^{192}$ There are differences in the methods used by these popular ranking platforms, such as the type of schools ranked, letter versus number systems, and methodology. ${ }^{193}$ This section will focus on Greatschools.org.

GreatSchools.org is a subsidiary of NewSchools.org, a California venture philanthropy firm that markets educational technology and expertise, among other things. ${ }^{194}$ NewSchools.org started Greatschools.org in 1998 to create an easier way for families to compare school quality. ${ }^{195}$ Greatschools.org rankings have grown in popularity, reporting that last year (2018) it had "more than 55 million unique visitors, including over half of American families with school-age children." 196 Viewership statistics demonstrate that school quality is a central factor when deciding where to buy a home, which is why Greatschools.org rankings have such a major impact on homebuyers' neighborhood choice.

Until two years ago, GreatSchools.org compared K-12 institutions using only raw test scores, rating schools on a scale 1 through 10 (low to high), and are further simplified by using three color-coded categories: red (1-3), yellow (4-7), green (8-10). ${ }^{197}$ The ratings did not take into account qualities that are more nuanced, such as scholastic offerings, school

190. Great Schools Ratings Methodology Report: Summary Rating, GREAT!SCHOOLS.ORG, https://www.greatschools.org/gk/ratings-methodology/ (last visited Feb. 22, 2019) (ranking with a color-coded, 1-10 ratings using "a multi-measured reflection of school quality").

191 .2019 Best School Districts in America, NICHE, https://www.niche.com/k12/search/ best-school-districts/ (last visited Feb. 22, 2019) (using color-coded, A-F for academics, teachers, and diversity).

192. See SCHOOL DigGER, https://www.schooldigger.com (last visited Feb. 22, 2019) (displaying rankings among U.S. state's 314 middle schools, with an accompanying star ratings).

193. SCHNEIDER, supra note 4, at 66-7 (noting varying ranking methods).

194. See generally Our Model, NewSChOOLS VENTURE Fund, https://www.newschools .org/about-us/our-model/ (last visited Feb. 22, 2019) (describing how charitable donations fund educators and entrepreneurs innovating public education).

195. Ralph Day, Educational Redlining: How Zillow and GreatSchools Profit from Suspect School Ratings and Harm Communities, HeIGHTS COMMUNITY CONGRESS, 3 (Nov. 2015), https://www.heightscongress.org/uploads/3/4/5/3/34532048/hcc_educational_redlining_great schools_ratings_on_zillow.pdf; see also SPENCER RASCOFF \& STAN HUMPHRIES, ZILLOW TALK: THE NEW RULES OF REAL ESTATE 66-68 (Laura Wyss et al. eds., 1st ed. 2015).

196. Licensing our data and content, GREAT!SCHOOLS.ORG: LICENSING, https://www.greats chools.org/gk/licensing/ (last visited Feb. 22, 2019) (commenting on frequency of user traffic).

197. Sara D. Sparks, School-Rating Site GreatSchools Expands Its Measuring Stick, EDUC. WEEK (Nov. 1, 2017), https://www.edweek.org/ew/articles/2017/11/01/school-rating-site-great schools-expands-its-measuring-stick.html (analyzing new GreatSchools.org methodology); see also Great Schools Ratings Methodology Report: Test Score Rating, GREAT!SCHOOLS.ORG, https:// www.greatschools.org/gk/ratings-methodology/\#methodology-test-score-rating (last visited Feb. 22, 2019) (discussing in detail rating methodology). 
environment, opportunities to think creatively, extracurricular activities, or suitability for a particular child. ${ }^{198}$ Schools that consistently receive low scores between one and three are often impoverished or low income communities of color. ${ }^{199}$ Predictors of low achievement are welldocumented by social scientists and include, for example, less access to health care, absenteeism, literate parents, adequate housing, and access to after school programming. ${ }^{200}$ As these predictors accumulate, children in poor social classes have lower average achievement than middle-class children, even if exposed to quality instruction. ${ }^{201}$ Also problematic is the gradual increase of isolation of low-income Black children. ${ }^{202}$ The share of Black students attending schools that are more than $90 \%$ minority has grown from $34 \%$ to $39 \%$ from 1991 to $2011 .^{203}$ These dynamics illustrate how testscore-based school ratings are more representative of race or poverty demographics than they are of school quality and can be easily misused by real estate agents in sales transactions. ${ }^{204}$ Lisa Rice, the executive vice president of the National Fair Housing Association, shared in an interview that some of her group's civil rights investigations found real estate agents describing the same schools using different metrics to White and Latino homebuyers, recommending a school to Latino parents that they had disparaged to White parents. ${ }^{205}$ This is yet another example of the troubling use of school race data in our modern real estate market. ${ }^{206}$

198. Day, supra note 195 , at 10 (noting inadequacy of school ranking metrics).

199. Kendra Yoshinaga, et al., Race, School Ratings And Real Estate: A 'Legal Gray Area', NPR: NPR ED (Oct. 10, 2016), https://www.npr.org/sections/ed/2016/10/10/495944682/raceschool-ratings-and-real-estate-a-legal-gray-area (discussing school rankings on real estate industry). Yoshinaga quotes assistant professor Genevieve Siegel-Hawley of Virginia Commonwealth University, an expert in race studies and housing - ' [a] lot of time, with schools that serve majorities of students of color, you get a negative rating because the test scores are low ... most of the variation in test scores is explained by the kids' own poverty or the poverty of their school.' Id.

200. Richard Rothstein, The Racial Achievement Gap, Segregated Schools, and Segregated Neighborhoods: A Constitutional Insult, 7 RACE \& SOC. PROBS. 21, 21-22 (2014).

201. Id. at 22 .

202. Id.

203. Id.

204. See Sparks, supra note 197 (commenting about potential misuse of test-score based rankings).

205. Id. (sharing interview comments by Lisa Rice regarding discriminatory use of school rankings). In the interview, Lisa Rice stated "information [ranking websites] are providing gives only a small snapshot of each school, and no one should make a decision to send their child to a school based only on the data in these websites." Id.

206. Though this paper focuses on the how agents and home-seekers use race data to guide the homebuying process, it is important to note that school rankings also have a significant impact on home valuations. See Tommy Unger, Affording a House in a Highly Ranked School Zone? It's Elementary, REDFIN: BLOG (Sept. 25, 2013), https://www.redfin.com/blog/2013/09/payingmore-for-a-house-with-a-top-public-school-its-elementary.html. Redfin looked at homes on MLS that sold between May 1 and July 13, 2013, to calculate median sale price and price per square 
In September 2017, GreatSchools.org launched an expansion of its school-rating system, intended to provide a more multifaceted measure of school quality by highlighting student test growth, achievement gaps (equity ratings), school climate, and course offerings. ${ }^{207}$ Prior to 2017, GreatSchools.org defined its ratings in a way that virtually guaranteed that schools in moderate income suburbs ranked below those in more affluent suburbs as ratings were largely being based on test scores, which research has consistently shown are highly correlated with students' socioeconomic status. It was also around September of 2017 that the race data embedded within school ranking charts featured on Zillow.com were removed.

The more expansive metrics and the removal of race information linked to real estate websites are steps in the right direction. The use of more nuanced metrics demonstrates that GreatSchools.org reacted to the many criticisms about over-simplified test score ratings. Now, GreatSchools.org provides race data broken down into sub-groups including test scores, college readiness, advanced AP coursework and absenteeism. ${ }^{208}$ GreatSchools.org also elaborates on equity ratings by displaying how students of color perform in comparison to their peers. ${ }^{209}$ By providing a more accurate picture of school quality online, homebuyers can make better choices about community fit when conducting independent research using GreatSchools.org.

Despite GreatSchool.org's efforts to have a more holistic picture of school quality, race information of any kind does not belong on real estate websites due to historical and current practice of how realtors use race information. The purpose of providing information about race and school quality appears to depend largely on market analysis ${ }^{210}$ by real estate marketplaces, which guides what type of information gets featured on webpages. ${ }^{211}$ The business incentive for providing certain data on real estate websites is clear; the more accessible the information and user friendly the

foot of homes within school zones. School zone boundaries were provided by Maponics (a company that provides commerce data, such as demographics, streets, neighborhoods, points of interests, and world boundaries for businesses to better market to target audiences). Id. School data and test scores were provided by Onboard Informatics, a marketing data provider, and GreatSchools.org. Id. The percentile rankings are based on test scores for each of the schools in this report. School and home coverage consisted of 10,811 elementary school zones across 57 metro area and included 407,509 home sales. Id.

207. About GreatSchools' Ratings: Our new approach to ratings, GREAT!SCHOOLS.ORG, https://www.greatschools.org/gk/summary-rating/ (last visited Feb. 12, 2019) (describing expansion of metrics used for school rankings).

208. Id.

209. Id.

210. Market Analysis Definition and Example, MARKET BUSINESS NEwS, https:// marketbusinessnews.com/financial-glossary/market-analysis/ (Oct 1, 2019) (defining market analysis). A market analysis is research on any market which aims to anticipate or predict the direction of prices or growth. $I d$.

211. Wiggin, supra note 157. 
visual medium, the more customers, clicks, exposure to real estate agents, ad campaigns, and ultimately money. Because Zillow Group depends largely on market analysis to guide what type of information is displayed online ${ }^{212}$ they can decide to feature GreatSchool.org charts detailing racial demographics to property listings at any time. ${ }^{213}$

The following sections highlight two strategies to prevent racial demographics from being featured on real estate websites in the future.

\section{What Can Be Done}

Technology is changing how people search and buy homes, which is why we must revolutionize the way we think about housing law. There is no easy way to address how real estate marketplaces use race data online because there is no straightforward enforcement mechanism. There does exist one plausible, yet complex strategy under the Fair Housing Actsegregative effect theory. Discussed in this section are some advantages and likely challenges with using segregative effect theory. ${ }^{214}$ In addition to litigation, a statutory update of the FHA is another prospect. Housing law will never fully catch up with innovation online, but the FHA can be updated with language that is more inclusive of websites that are in the business of property sales and rentals and allows for some leeway for future interpretation.

\section{A. Synopsis of Segregative Effective Theory}

In 2013, HUD issued a rule that established the standards governing discriminatory effect claims under the FHA. ${ }^{215}$ The regulation sets forth the basic three-step, burden-shifting framework applicable to all discriminatory

212. Id. (commenting on business discretion).

213. Id. (noting potential for reappearance of race data).

214. See Tex. Dep't of Hous. \& Cmty. Affairs v. Inclusive Cmtys. Project, Inc., 135 S. Ct. 2507, 2522-24 (2015) (discussing comprehensive overview of discriminatory effect theory). The Court properly tied the proper analysis of disparate-impact claims under the FHA to their counterpart under the federal employment discrimination law, specifically Title VII of the 1964 Civil Rights Act). Id. See also 42 U.S.C. \$2000(e) (2015) (codifying Title VII).

215. Robert G. Schwemm, Segregative-Effect Claims Under the Fair Housing Act, 20 N.Y.U. J. LEGIS. \& PUB. POL'Y. 710, 710 (2017) (citing implementation of Fair Housing Act's discriminatory effects standard, 78 Fed. Reg. 11,460, 11,482 (Feb. 15, 2013)). Schwemm discusses Meyers v. Holley, 537 U.S. 280, 287-88 (2003) and 24 C.F.R. $\$ 100.500$ (2013) pointing out that the Meyers Court asserted that HUD formalizes discriminatory effects liability under the Act for "purposes of ... consistency ... [and provides for a] burden-shifting test" to determine liability under the Act. $I d$. 
effect claims, regardless of whether they are based on disparate-impact or segregative-effect theory. ${ }^{216}$

Under the 2013 regulation, all discriminatory effect cases must be analyzed in three steps: 1) the plaintiff must establish a prima facie case proving the challenged practice caused or will cause a discriminatory effect; 2) the burden shifts to the defendant to prove that its challenged practice is necessary to achieve one or more substantial, legitimate, nondiscriminatory interests; and 3) if the defendant satisfies the burden, the plaintiff may still prevail by proving that the defendant's interest could be served by a less discriminatory alternative. ${ }^{217}$ In a case against real estate websites, this burden-shifting approach leaves room for argument on both sides.

If a plaintiff established a prima facie case of discriminatory effect, a real estate website could argue that providing data based on market studies for the purpose of increasing viewership and revenue is a nondiscriminatory interest. The plaintiff could counter that websites with more comprehensive and representative data sets, such as local government pages, are a less discriminatory alternative than direct property links. These basic arguments can potentially work under segregative effect theory, but establishing a prima facie case of discriminatory effect calls for further examination.

The HUD regulation authorizes and distinguishes between the two main types of discriminatory effect claims that do not require a showing of illegal intent: a) disparate impact ${ }^{218}$ and b) segregative effect. ${ }^{219}$ The main difference between the two theories turns on who is being harmed. In disparate impact cases, the harm occurs to a particular group of people in a protected class; in segregative effect cases, the harm occurs to a community by "creating, increasing, reinforcing, or perpetuating segregated housing patterns." 220 The "increasing" and "reinforcing" language is a portion of the theory that has rarely been used. ${ }^{221}$ This underdeveloped area of the law

216. Id. at 713 (establishing discriminatory effect analysis).

217. Id. at 712-13 (stating three-step analysis).

218. See 24 C.F.R. $\$ 100.500$ (2017). The C.F.R. states "[I]iability may be established under the Fair Housing Act based on a practice's discriminatory effect ... even if the practice was not motivated by a discriminatory intent." $I d$.

219. 24 C.F.R. $\$ 100.500$ (a) (2017). Discriminatory effect is defined as "a practice ... where it actually or predictably results in a disparate impact on a group of persons or creates, increases, reinforces, or perpetuates segregated housing patterns because of race, color, religion, sex, handicap, familial status, or national origin." $I d$.

220. Schwemm, supra note 215, at 713 (citing Effects Standard, 78 Fed. Reg. at 11,469).

221. Id. at 743 (suggesting segregative effect theory has broad application); see also Shannon v. U.S. Dep't of Hous. \& Urban Dev., 436 F.2d 809 (3rd Cir. 1970). In Shannon, an early challenge to HUD's approval of a heavily minority project in a city's minority neighborhood was upheld. Id. at 814. The court agreed that the location of the housing project on the site chosen will have the effect of increasing the already high concentration of low-income black residents in the East Poplar Urban Renewal Area violating HUD's responsibilities under the FHA. Id. at 812 . 
leaves room for novel applications of segregative effect theory and should be further explored by fair housing litigators.

Legal ambiguity is helpful for a unique case against real estate websites using segregative effect theory. But, HUD's burden-shifting model $^{222}$ still presents some challenges to a plaintiff bringing a potential claim. In a case against real estate websites, posting race data linked to property listings is a practice worth confronting. Yet, identifying the practice at issue is simpler for the plaintiff than meeting the burden of a prima facie case. Assuming the plaintiff has standing to sue, ${ }^{223}$ they must do three things: 1) identify the challenged practice, 2) show, through statistical evidence, that this practice exacerbates segregation in a particular community to a sufficiently large degree, and 3 ) prove that the challenged practice actually caused a segregative effect. ${ }^{224}$ The language in the second prong implies that a plaintiff must provide a statistical analysis showing a certain practice exacerbates segregation within a specific geographic location. Unlike disparate impact cases, which focus on harm caused to protected classes and generally requires complex statistical analysis, ${ }^{225}$ segregative effect cases have historically focused on more insular areas. ${ }^{226}$

According to Robert Schwemm's analysis of segregative effect theory, the language in the theory is limited to communities that have been harmed, which provides for a more straightforward evaluation of segregation because it relies on local census data." 227 Another pertinent question related to statistical representation is what it means to have an impact of a sufficiently large degree. There is no HUD guidance in segregative effect cases related to what Schwemm terms as the "how much" issue, ${ }^{228}$ which again provides opportunity for legal exploration. Local census data may be enough to show

222. See 24 C.F.R. $\$ 100.500$ (c) (2017).

223. See 42 U.S.C. $\$ \S 3602$ (d)-(i)(1) (outlining standing to sue). For a plaintiff to have standing under the FHA, they must be an aggrieved person who claims to have been injured by a discriminatory housing practice. Id. An aggrieved person has been interpreted broadly by the courts. Id.; See also Bank of Am. Corp. v. City of Miami, Fla., 137 S.Ct. 1296, 1303 (2017) (defining aggrieved person). The Court stated the FHA's definition of person "aggrieved" reflects a congressional intent to confer standing broadly as is permitted by Article III of the Constitution. Id.

224. 24 C.F.R. $\$ 100.500$ (c) (2017).

225. See Inclusive Cmtys. Project, Inc., 135 S. Ct. at 2523 (clarifying that causation requires statistical analysis). The Court stated that a disparate-impact claim relying on statistical disparity must fail if the plaintiff cannot point to a defendant's policy or policies causing that disparity. Id.

226. See United States v. City of Black Jack, 508 F.2d 1179, 1183-85 (8th Cir. 1974) (upholding challenge to zoning ordinance). The court prohibited a discriminatory zoning ordinance causing a segregative effect. $I d$. The defendant city prevented multi-family affordable units from being built in its primarily white, single-family community. Id.; see also Schwemm, supra note 215, at 716 (highlighting importance of Black Jack case in segregative effect theory).

227. Schwemm, supra note 215 , at 738 (analyzing boundaries for establishing segregative effect under FHA).

228. Id. at 742-43 (examining how much discrimination must be shown to prove a segregative effect). 
a segregative effect under more conventional fact patterns, such as zoning cases or housing project disputes, but the connection between the online space and its impact on certain communities is more esoteric. To successfully build a case against real estate websites, an empirical study, whether simulated or in real time, showing a statistically significant relationship between school rankings with race data and racial steering must be conducted. This type of statistic does not yet exist. But, considering outcomes derived from testing studies, demonstrating a statistical relationship between steering and race data linked to property listings is a reasonable possibility. ${ }^{229}$

\section{Proposed Plaintiff}

Any aggrieved person, enforcement agency, or non-profit organization whose mission centers on housing, can bring a claim against a real estate website under the FHA. ${ }^{230}$ An individual plaintiff may not want to expend their resources on a claim that may not have an immediate result or direct relief; still, if they are represented by a fair housing organization, an individual may be inclined to sue on their community's behalf. ${ }^{231}$ A government enforcement agency or local municipality may have more of an incentive to bring a claim because their purpose is to uphold the law as proscribed and further the public interest. ${ }^{232}$

There are three mechanisms by which a plaintiff may bring a claim under the FHA: 1) by filing a complaint with HUD, which may lead to an administrative hearing or court suit; ${ }^{233} 2$ ) by filing directly with local courts; and 3); an action may be initiated by the Attorney General. ${ }^{234}$ Regarding the first option, the FHA provides the Secretary, "on the Secretary's own

229. Id. at 739-41 (noting statistical evidence courts have used to make findings of segregative effect). Even if real estate websites are legally prohibited from featuring race data on property listings, it does not necessarily mean that agents themselves will not continue to steer inperson. However, the same can be said for any law that forbids undesirable or dangerous behavior.

230. 42 U.S.C. $\$ 3610($ a)(1)(A)(i) (stating complainants under Act); see also $\$ \$ 3602$ (d), (i)(1) (defining "aggrieved person"); Havens Realty Corp. v. Coleman, 455 U.S. 363, 373-75 (1982) (establishing standing to sue for frustration of mission); 42 U.S.C. $\$ 3614$ (a) (authorizing Attorney General to bring pattern and practice cases).

231. Havens Realty Corp., 455 U.S. at 374-79 (holding that organizations and testers can be plaintiffs under the FHA). The Court unanimously upheld the claims of a fair housing organization and a black tester who had been falsely informed by the defendant agent that no units were available in its apartment complex. Id. at 374-75.

232. See Memorandum of Understanding between DOJ and HUD Concerning Enforcement of the Fair Housing Act, as Amended by the Fair Housing Act of 1988, 1 (Dec. 7, 1990) (on file with author).

233. See 42 U.S.C. $\$ 3610($ a)(1)(A)(i) (complainant may file with Secretary within one year).

234. Id. at $\$ 3614(\mathrm{a})$. 
initiative," may file a complaint, ${ }^{235}$ otherwise known as a secretary-initiated complaint. A recent example of a secretary-initiated complaint occurred in August, 2018 when Assistant Secretary for Fair Housing and Equal Opportunity ("FHEO"), Anna Maria Farias, filed a complaint against Facebook for violating the FHA. ${ }^{236}$ Since the filing, the FHEO found that reasonable cause exists to believe that Facebook, Inc. engaged in discriminatory housing practices and authorized an official Charge against the company. ${ }^{237}$ The complaint (and now charge) filed by the Assistant Secretary is one of the first to be brought against a social media giant for alleged FHA violations and was initiated as a matter of public importance. Likewise, HUD would be well-suited to bring a similar complaint against real estate marketplaces for using race data linked to real estate postings because they may have the resources to collect the necessary statistical evidence to bring such a claim. ${ }^{238}$ If HUD has reason to believe that a complaint suggests a pattern or practice of housing discrimination, it may refer the case to the DOJ. ${ }^{239}$ Further, the DOJ may file their own department-initiated complaint if they suspect pattern or practice violations that amount to issues of public importance. ${ }^{240}$ This article has laid foundation for why using race data linked to real estate listings is a matter of public importance and violates the spirit of the FHA. Whether or not the current administration has the political will to file such a claim is a question that is outside the scope of this paper. It is possible future administrations may undertake such an endeavor.

235. Id. at $\$ 3610(\mathrm{a})(1)(\mathrm{A})(\mathrm{i})$.

236. Hous. Discrimination Complaint, supra note 150. The complaint alleges that Facebook violated the FHA by using ad targeting tools that enabled advertisers of housing-related services to discriminate. Id. at 2. The complaint gives several examples, including "enabling advertisers to discriminate based on race and color by drawing a red line around majority-minority zip codes and now showing ads to users who live in those zip codes." Id.

237. Charge of Discrimination, The Secretary, United States, Department of Housing and Urban Development, on behalf of Complainant, Assistant Secretary for Fair Housing and Equal Opportunity v. Facebook, Inc., No. 01-18-0323-8 (outlining allegations and legal authority), available at https://www.hud.gov/sites/dfiles/Main/documents/HUD_v_Facebook.pdf (last visited Aug. 16, 2019).

238. Funding Opportunities, HUD.GOv, https://www.hud.gov/grants (last visited Feb. 22, 2019). HUD offers numerous grant opportunities for fair housing organizations and enforcement agencies. Id . With these grants, HUD may be able to fund a project focused on investigating the occurrence of steering on real estate websites using Fair Housing Assistance Programs or a Fair Housing Initiatives Programs. Id.

239. 42 U.S.C. \$ $3610(\mathrm{e})(2)$

240. 42 U.S.C. $\$ 3614$ (a) (authorizing DOJ initiated complaint). If there is reasonable cause to believe that any person or group of persons is engaged in a pattern or practice of resistance to the full enjoyment of any rights granted by the FHA, or that any group of persons has been denied any of the rights granted by the FHA and such denial raises an issue of general public importance, the DOJ may file a complaint. $I d$. 


\section{B. Potential Statutory Updates}

The FHA, state, and local municipal laws prohibit discrimination in housing practices against protected individuals. ${ }^{241}$ While fair housing laws allow for limited, narrowly tailored exemptions for certain protected groups, ${ }^{242}$ these exemptions never apply to real estate professionals or anyone in the business of renting dwellings. ${ }^{243}$ Furthermore, fair housing laws regulate the actions of real estate professionals but do not necessarily regulate collaborations between agents and consumers using real estate websites. The FHA's language should be updated to include within its authority online housing markets.

\section{Update FHA Section 3604}

Under 42 U.S.C. 3604(a), the law states that it is unlawful "[t]o otherwise make unavailable or deny, a dwelling to any person because of race, color, religion, sex, familial status, or national origin." This portion of the FHA has been interpreted by courts to encompass the practice of illegal steering. ${ }^{244}$ Historically, the language "to ... make unavailable or deny, a dwelling ..." has been interpreted broadly. ${ }^{245}$ However, the language has not yet been interpreted to include steering that may occur as a result of race data posted on real estate websites. Race data linked to real estate advertisements have a strong potential to steer consumers away from low to moderate income communities of color, an effect that contributes to disinvestment and patterns of segregation. ${ }^{246}$ To combat steering and discrimination perpetuated by real estate websites, FHA Sections 3604 and 3605 should include language that

241. See, e.g., 42 U.S.C. $\$ 3601$ et seq.; M.G.L. c. 151B, \$4; Boston, MA., CODE C. (2002).

242. 42 U.S.C. $\$ 3607$ (a). When renting a property, religious organizations, associations, or societies may limit or give preference to persons of the same religion, provided that, membership in such religion is not restricted on account of race, color or national origin. Id.

243. 42 U.S.C. $\$ 3605$ (a) (stating discrimination by a person engaged in real estate transactions is unlawful); see also 42 U.S.C. $\$ 3602$ (b) (defining a dwelling). A dwelling is any building, structure, or portion thereof which is occupied as, or designed or intended for occupancy as, a residence by one or more families, and any vacant land which is offered for sale or lease for the construction or location thereon of any such building, structure, or portion thereof. Id.

244. Zuch, 394 F. Supp. at 1047 (holding steering is prohibited by 3604(a) of the Fair Housing Act which makes it unlawful to "otherwise make unavailable or deny, a dwelling to any person" on the basis of race).

245. See, e.g., Laufman v. Oakley Bldg. \& Loan Co., 408 F. Supp. 489, 493 (1976) (commenting on broad interpretation of what constitutes denial of housing); United States $v$. Youritan Constr. Co., 370 F. Supp. 643, 648 (1973), modified on other grounds, 509 F.2d 623 (1975) (stating language "appears to be as broad as Congress could have made it").

246. See generally, Turner, et al., supra, note 89 (analyzing prevalence of racial steering and discrimination in cities). 
specifically mentions online tools and platforms used by licensed real estate agents for the purpose of marketing sales and rentals of homes.

One proposed change to 42 U.S.C. 3604(a) that could effectively address the issue of steering created by the display of student race and ethnicity data on real estate websites is to include at the beginning of 3604(a) the following language: "it shall be unlawful for any person, entity, or online entity whose primary business and use is for the purpose of the sale, rental, or advertisement of real estate ...." The proposed language at the beginning of the subsection would include real estate websites, like Zillow.com and the like, and hold their enterprises accountable for displaying information that real estate professionals themselves are discouraged to provide in-person due to a long history of using school information as a proxy for race. While including the term "primary business" would encompass real estate websites and potentially other sharing economies online, the CDA would still provide content freedom for certain platforms, like Craigslist.com. ${ }^{247}$

\section{Update FHA Section 3605}

Under 42 U.S.C. 3605(a), it is illegal "for any person or other entity whose business includes engaging in residential real estate-related transactions to discriminate against any person in making available such a transaction, or in the terms or conditions of such a transaction, because of race, color, religion, sex, handicap, familial status, or national origin." A residential real estate transaction is defined as "the making or purchasing of loans or providing other financial assistance ... [and] the selling, brokering, or appraising of residential real property. ${ }^{248}$ One option to update the statute under this section is to include language that details "it is unlawful for any person or other entity whose business includes engaging in residential real estate-related transactions including online tools or platforms used for real estate-related transactions or advertisements, to discriminate against any person in making available such a transaction."

Several cases have interpreted the construction of "real estate-related transactions" to encompass the making and purchasing of mortgage loans ${ }^{249}$ and the issuance of insurance as under the purview of "other financial assistance," 250 in addition to other home purchase requirements. The

247. CRAIGSLIST, https://www.craigslist.org/about/sites (last visited Oct. 6, 2019). Craigslist's primary business is not necessarily real estate, but rather a platform for information and advertisements in many different markets. Id.

248. 42 U.S.C. $\$ 3605(\mathrm{~b})$; Nothing in the title prohibits a person engaged in the business of appraisals of real property from considering factors other than protected categories. 42 U.S.C. $\S$ $3605(\mathrm{c})$.

249. Eva v. Midwest National Mortgage Bank, Inc., 143 F. Supp. 2d 862, 886 (2001).

250. Viens v. America Empire Surplus Lines Ins. Co., 113 F. Supp.3d 555, 569-71 (2015) 
"selling" or "brokering" of real estate included in the definition is exactly what real estate websites, by their very nature, are designed to do. However, no case law exists as to whether the language "real estate-related transactions" includes activities on real estate websites as a result of referrals via electronic communications, information gathering, and other online exchanges. Real estate websites are so closely intertwined with the work of agents that "real estate-related transactions" occur regularly as a result of features available on real estate websites, especially when considering the plain meaning of "transaction," which is an activity involving two or more persons. ${ }^{251}$ Many transactions occur between consumers and agents advertising their listings and business on Zillow.com and Redfin.com. Providing the proposed transaction language above enables an additional enforcement tool to prevent race data from being posted on real estate marketplaces.

\section{Conclusion}

The way consumers search for homes today has been transformed by innovation and technology. A significant number of homebuyers start their home buying process online and scour real estate marketplaces using location and price filters, among many other criteria. Consumers have access to thousands of homes online and naturally want to find a way to narrow property options. Property listings on sites like Zillow.com and Redfin.com are posted by licensed real estate professionals who are subject to fair housing laws. If agents use these online tools to amplify their property listings, the posted listings should comport with how agents must advertise listings on any other medium - race data not included.

Providing race data of any kind, without direct consumer solicitation, has been deemed illegal steering, depending on the agent's intent. It would be very difficult to determine real estate companies have intent to steer because they feature student race information on their websites, but it is feasible to isolate whether or not posting race data has a segregative effect on communities of color. Testing studies prove that real estate professionals have and continue to discriminate and steer using race information and school quality comments. For this reason, race and ethnic demographic data does not belong on tools used heavily by real estate agents for marketing purposes. The practice should be prevented legally by either courts of law using segregative effect theory or by Congress amending the Fair Housing Act.

(holding property and commercial general liability insurance policies could fit within definition of residential real estate-related transaction); 42 U.S.C. \$ 3605(a).

251. Transaction, BLACK's L. DiCTIONARY (11th ed. 2019). Black's Law Dictionary defines, "transaction" as "[t]he act or an instance of conducting business or other dealings; esp., the formation, performance, or discharge of a contract. 2. Something performed or carried out; a business agreement or exchange. 3. Any activity involving two or more persons . . " Id. 
